TAPROBANICA, ISSN 1800-427X. May, 2021. Vol. 10, No. 01: pp. 23-38, pls. 3-8.

(C) Research Center for Climate Change and Department of Biology, Faculty of Mathematics \& Natural Sciences, University of Indonesia, Depok 16424, INDONESIA.

http://www.taprobanica.org

https://doi.org/10.47605/tapro.v10i1.245

\title{
TWO NEW RUPICOLOUS DAY GECKOS OF THE Cnemaspis alwisi GROUP (REPTILIA: GEKKONIDAE) FROM SRI LANKA
}

\author{
A.A. Thasun Amarasinghe ${ }^{1}$, Suranjan Karunarathna ${ }^{2}$, Majintha Madawala ${ }^{3} \&$ Anslem de Silva $^{4}$ \\ ${ }^{1}$ Departemen Biologi, Fakultas Matematika dan Ilmu Pengetahuan Alam, Universitas Indonesia, Kampus UI, \\ Depok, 16424, Indonesia; E-mail: thasun.amarasinghe@ui.ac.id \\ ${ }^{1}$ Association of Asian Herpetology (Asosiasi Herpetologi Asia), Jl. BSD Bintaro No. 88, Pondok Aren 15228, \\ Tangerang Selatan, Indonesia \\ ${ }^{2}$ Nature Explorations \& Education Team, No: B-1 / G-6, De Soysapura Flats, Moratuwa 10400, Sri Lanka; \\ E-mail: suranjan.karu@gmail.com \\ ${ }^{3}$ Victorian Herpetological Society, P.O. box 4208, Ringwood, VIC 3134, Australia \\ ${ }^{4}$ Amphibia \& Reptile Research Organization of Sri Lanka, 15/1, Dolosbage Road, Gampola, Sri Lanka
}

\begin{abstract}
We investigated diminutive day geckos of the genus Cnemaspis in Sri Lanka, and based on morphological evidence, two populations belonging to the $C$. alwisi group within the $C$. podihuna clade are described. Both populations are morphologically closely allied to $C$. hitihamii, but can be clearly distinguished based on a combination of morphological characters, hence named here as two new species. The two new species occur respectively in (i) lowland dryzone (alt. $385 \mathrm{~m}$ a.s.l.) forests which have a dense tree cover in Ritigala Nature Reserve, Anuradhapura District and (ii) lowland wetzone (alt. $50 \mathrm{~m}$ a.s.l.) forests and adjacent human habitations which have a dense tree cover in Gampaha District, near Colombo, the capital of Sri Lanka. We also update the available key for these and previously recognized species from Sri Lanka, based on collected material and literature.
\end{abstract}

Key words: Colombo, Cnemaspis hitihamii, Ritigala Nature Reserve, urban biodiversity, taxonomy

\section{Introduction}

Sixteen new species of the genus Cnemaspis Strauch, 1887 have been discovered from Sri Lanka during the past five years (Batuwita \& Udugampala 2017, Batuwita et al. 2019, de Silva et al. 2019, Karunarathna \& Ukuwela 2019, Karunarathna et al. 2019a-c, Amarasinghe \& Karunarathna 2020, Karunarathna et al. 2021). The genus Cnemaspis is highly species-rich and geographically widespread in Africa and South \& Southeast Asia, and has been shown to be polyphyletic (Gamble et al. 2012, Grismer et al. 2014). The Sri Lankan species fall into two broad divergent groups among the South Asian lineage: the podihuna and kandiana clades (Agarwal et al. 2020, Karunarathna et al. 2021). Based on Karunarathna et al. (2019b, 2021) and Amarasinghe \& Karunarathna (2020), the podihuna clade currently comprises 16 species 
in Sri Lanka. The same authors further identified three groups (subclades) within the podihuna clade: currently (1) the scalpensis group consisting of five species ( $C$. anslemi, $C$. geтипи, C. godagedarai, C. phillipsi, $C$. scalpensis); (2) the podihuna group consisting of four species ( $C$. kandambyi, $C$. manoae, $C$. molligodai, $C$. podihuna); and (3) the alwisi group consisting of seven species (C. alwisi, $C$. hitihamii, C. kohukumburai, $C$. nilgala, $C$. punctata, $C$. rajakarunai, $C$. rammalensis).

During museum reference work in 2015, we found two specimens identified as " $C$. alwisi" among the collections of the National Museums of Sri Lanka, along with the rediscovery of $C$. tropidogaster (see Amarasinghe et al. 2016) and a new species, C. manoae (see Amarasinghe \& Karunarathna 2020). These specimens were collected from Pilikuttuwa and Maligatenna in Gampaha District, Western Province, and provisionally identified as $C$. cf. alwisi. Again, during museum reference work in 2016, we found three more specimens of "Cnemaspis alwisi" among the collections of NMSL. These specimens were collected from Ritigala forest in Anuradhapura District, North Central Province, and also provisionally identified as $C$. cf. alwisi. Although it was peculiar to find the intermediate biogeographical zone species Cnemaspis alwisi in both the wet zone and the dry zone (see the map in figure 4 provided by Amarasinghe \& Karunarathna 2020), we had not previously compared them to the types of all Sri Lankan Cnemaspis. Therefore, here we sought to compare those specimens to confirm their identity. Upon closer examination, it was clear that these specimens represent two distinct, unnamed species belonging to the alwisi group, allied to $C$. hitihamii, but morphologically clearly distinct. Hence we describe them as new species.

\section{Material and methods}

The type series of both new species are currently stored in $70 \%$ ethanol. We examined the type specimens representing all the Sri Lankan species of the podihuna clade (Appendix I), including available voucher specimens. Assignment of unidentified specimens to species was based on the presence of shared morphometric and meristic characters. Museum acronyms follow Uetz et al. (2019). Specimens were examined at the British Museum, London, UK (NHMUK); National Museum of Sri Lanka, Colombo, Sri Lanka (NMSL); and Wildlife
Heritage Trust, Colombo, Sri Lanka (WHT). The WHT collection has now been deposited at NMSL but is currently uncatalogued. When diagnosing and describing the new species, we scored specimens for the same morphological characters used in recent descriptions of members of the podihuna clade (e.g., Manamendra-Arachchi et al. 2007, Amarasinghe \& Campbell 2016, Karunarathna et al. 2019b, and Amarasinghe \& Karunarathna 2020). Measurements were obtained from the left side of the body to the nearest $0.1 \mathrm{~mm}$ using Mitutoyo digital calipers under a Leica-Wild M3Z dissecting microscope.

We measured snout-vent length (SVL, from tip of snout to anterior margin of vent), axillagroin length (from the posterior margin of the forelimb at its insertion point on the body to the anterior margin of the hind limb at its insertion point on the body), head length (from posterior edge of mandible to tip of snout); head width (maximum width of head at the angle of the jaws), orbit diameter (the greatest diameter of the orbit); orbit-ear length (from posterior border of orbit to anterior border of tympanum), snout length (from anterior border of orbit to tip of snout), orbit-nostril length (from anterior border of orbit to posterior border of nostril), interorbital width (shortest distance between dorso-medial margins of orbits), ear diameter (greatest diameter of tympanum), internarial length (shortest distance between dorsal margins of nostrils), brachium length (on the dorsal surface from the axilla to the inflection of the flexed elbow), antebrachium length (on the dorsal surface from the posterior margin of the elbow while flexed to the inflection of the dorsiflexed wrist), palm length [from wrist (carpus) to distal tip of longest finger], finger lengths $\mathrm{I}-\mathrm{V}$ (from tip of claw to the nearest fork), thigh length (from the anterior margin of the hind limb at its insertion point on the body to the knee while flexed), shank length (from the posterior surface of the knee while flexed to the base of the heel), foot length (from heel to tip of longest toe), toe lengths I-V (from tip of claw to the nearest fork), and tail length (from posterior margin of vent to tip of tail). We counted supralabial and infralabial scales (from the gape of mouth to the rostral and mental scales, respectively), ventrals (all the scales from the mental to the last scale bordering the anterior vent along the midventral line), scale rows across belly (the number of longitudinal ventral scale rows at midbody), midbody scale rows 
(total number of longitudinal scale rows around the midbody including both dorsal granules and ventral scales). Paravertebral granules were counted from the neck until the level of cloaca along the vertebral line. We counted subdigital lamellae on each finger and toe $\mathrm{I}-\mathrm{V}$, from the first proximal enlarged scansor wider than the width of the largest palm scale to the distal-most lamella (excluding the claw sheath) at the base of the claw. We also counted the total number of precloacal and femoral pores and assessed their orientation. The number of non-pored scales (interfemoral scales) between pore-bearing femoral rows on both femurs was counted. We measured the degree and arrangement of body and tail tuberculation texture (homogeneous or heterogeneous), spinous scales on flanks, and the relative size and morphology of the subcaudal scales. We evaluated the texture of the scales on the ventral surface of brachium and antebrachium. We sexed specimens by examining everted hemipenes or hemipenial bulges at the tail base. To view some small characters such as keeling of the ventrals, we applied the reversible stain methylene blue in $70 \%$ ethanol, following Amarasinghe et al. (2015). The risk of extinction of the species was evaluated using the IUCN Standards and Petitions Subcommittee (2019) guide.

\section{Results}

Two new species of the alwisi group (podihuna clade) are described here. They are endemic to Sri Lanka and confined to isolated rocky hills in the lowland wet zone and the lowland dry zone respectively of Sri Lanka. We present comparative morphometric and meristic data obtained for the type specimens (Table 1). Interspecific comparisons of morphological and meristic characters (discrete or non-discrete) revealed a suite of characters that distinguish the new species from congeners (Table 2). In the diagnosis and identification keys, we summarize the differences between all known Sri Lankan Cnemaspis species.

\section{Taxonomy}

Cnemaspis gunasekarai sp. nov.

[urn:lsid:zoobank.org:act:2BA39BB9-C263-4C48-9B6EC829D1F70428]

(Figs. 1-3, 6, 7, Tables 1-4)

Cnemaspis alwisi - Agarwal et al. 2017

Holotype. Adult male, NMSL 2019.17.01, SVL $34.6 \mathrm{~mm}$, collected from Ritigala $\left(8^{\circ} 05^{\prime} 27.63^{\prime \prime}-\right.$ $8^{\circ} 09^{\prime} \quad 5.19^{\prime \prime} \mathrm{N}, \quad 80^{\circ} 37^{\prime} 28.62^{\prime \prime}-80^{\circ} 41^{\prime} 22.53^{\prime \prime} \mathrm{E}$, WGS1984, alt. $385 \mathrm{~m}$ a.s.1.), Anuradhapura District, North Central Province, Sri Lanka, by Anslem de Silva on 10 November 2005.

Paratypes $(\boldsymbol{n}=\mathbf{2})$. Adult females, NMSL 2019.17.02, SVL $31.1 \mathrm{~mm}$; NMSL 2019.17.03, SVL $28.6 \mathrm{~mm}$; other details are the same as holotype. See Table 1 for morphometric and meristic characters.

Diagnosis. The following combination of characters distinguishes this new species from all other congeners: adult males reaching 34.6 $\mathrm{mm}$ SVL, adult females reaching $31.1 \mathrm{~mm}$ SVL; 9-11 supralabials; dorsal granules homogeneous, 117-126 paravertebral granules; four or five spine-like tubercles on flanks; throat, pectoral, and abdominal scales smooth; 119-127 ventrals; no precloacal pores and ten femoral pores (per thigh) in males, 16 interfemoral scales; 89-95 midbody scales, 2022 ventral scale rows across belly; 19-21 subdigital lamellae on fourth toe; subcaudals smooth, subhexagonal shaped, median row of subcaudals greatly enlarged; the differences are summarized for geographically close congeners (Table 2) and for all Sri Lankan species in Karunarathna et al. (2019c, and their table 9).

Description of holotype. Characters of holotype followed, when appropriate, by those of paratypes (NMSL 2019.17.02, 03) in parenthesis. An adult male, $34.6 \mathrm{~mm}$ SVL (females 31.1, $28.6 \mathrm{~mm}$ ); head moderately large, elongate, narrow, distinct from neck, its length $28.6 \%$ of SVL $(31.0 \%, 33.5 \%)$; head width $49.5 \%$ of head length $(47.4 \%, 47.9 \%)$ and $14.2 \%$ of SVL $(14.8 \%, 16.1 \%)$; snout elongate, its length $75.5 \%$ of head width $(76.1 \%, 76.1 \%)$ and greater than orbit diameter; orbit diameter $91.9 \%$ of snout length $(91.4 \%, 91.4 \%)$; interorbital region narrow; interorbital distance $38.4 \%$ of head length $(38.1 \%, 38.5 \%)$; eye large, orbit diameter $34.3 \%$ of head length $(33.0 \%$, $33.3 \%$ ); pupil rounded; ear-opening deep, oval; diameter of orbits greater than orbit to ear distance, orbit-ear distance $85.3 \%$ of orbit diameter $(84.4 \%, 84.4 \%)$; scales of snout smooth, larger than those of occipital region; scales of interorbital, superciliary, and gular regions granular; rostral scale partially divided by medial groove, postero-ventrally in contact with first supralabial, contacted posteriorly by two nasals and two subcircular supranasals; two internasal scales between supranasals; nostrils oval, dorsally orientated; three postnasals, lowest in broad contact with first and second 
supralabials; nasals in broad contact with first supralabial.

Mental subtriangular, elongate and lengthened posteriorly to level of first supralabial, wider than long, postero-laterally in contact with two enlarged postmentals; postmentals medially separated by a single postmental scale; postmentals bordered posteriorly by three smooth scales on both sides, including the medial scale; scales on throat smooth, juxtaposed; bluntly pointed scales on side of neck, similar in size to those at middorsum; three scale rows separating orbit from supralabials at level of pupil; 10 supralabials $(9$, 10); 9 infralabials $(8,9)$, decreasing in size towards angle of jaw.

Body slender, elongate; axilla-groin distance $42.2 \%$ of SVL $(42.4 \%, 45.1 \%)$; middorsal granules bluntly pointed, homogeneous, keeled; five $(5,4)$ spine-like tubercles on flank; dorsal scales at midbody smaller than ventrals at same level; paravertebral granules 126 (119, 117); pectoral and abdominal scales subequal in size, smooth, bluntly pointed, overlapped; ventral scales in $22(20,21)$ rows across belly, ventro-lateral scales on trunk bluntly pointed and smooth; no distinct ventrolateral fold; scales around midbody $95(89,91)$; ventrals 127 (119, 122); no precloacal pores and ten femoral pores (absent as paratypes are females).

Arms moderately short; length of brachium $15.9 \%$ of SVL $(16.4 \%, 17.8 \%)$; length of antebrachium $14.4 \%$ of SVL $(15.4 \%, 16.8 \%)$; legs relatively long; shank length $17.6 \%$ of SVL $(16.4 \%, 17.8 \%)$; thigh longer than shank, its length $17.9 \%$ of SVL $(18.6 \%, 19.9 \%)$; dorsal scales on both arms and legs bluntly pointed and enlarged; ventral scales on brachium and antebrachium granular and smooth, scales on ventral surface of thigh bluntly pointed and smooth; digits elongate, slender, all bearing slightly recurved claws; subdigital lamellae entire, 21 on toe IV $(20,21)$; inter-digital webbing absent; relative lengths of fingers and toes IV > III > V > II > I.

Tail complete, original; tail base swollen; a pair of post-cloacal spurs; dorsal scales on tail bluntly pointed, imbricate, and smooth; dorsal tail scales homogeneous and enlarged in size; dorsal tail with 2-3 enlarged obtuse scales forming whorls on anterior tail; subcaudal scales at tail base small, bluntly pointed, enlarged and smooth; median subcaudal row enlarged and hexagonal; some enlarged subcaudals divided in to two scales randomly.
Variation. See Table 1.

Coloration. In life, the holotype had a dorsal pattern of cream vertebral markings on a uniform yellowish brown background color; snout dark yellowish brown; behind the eye, two dark brown blotches; the neck had a bright yellow and black stripe, and a vertebral cream stripe shading posteriorly; several pale and dark blotches scattered on the dorsum; arms and legs uniform light brown with pale and dark blotches; yellowish brown tail had ten pale yellow markings; ventral head white, pectoral area pinkish violet, abdomen shaded bright yellow, tail bright orangish yellow, palm and foot gray; dorsal side of hand and leg with black cross stripes.

After 15 years in preservative, the cream pigment has faded to white and the yellowish brown background color to grayish brown. The ventral body, head, and tail faded to cream; palm and foot gray.

Etymology. The specific epithet is a noun in the genitive singular case, honoring a leading environmental activist, conservationist, and former Deputy Director of Sri Lanka Customs (Government of Sri Lanka), Mr. Samantha Gunasekara, for his dedication and contributions to biodiversity conservation in Sri Lanka, as well as his generous friendship and support towards the authors. His valuable contributions to the Sri Lanka Customs Department in controlling biodiversity trafficking, illegal pet trade, and biopiracy, as well as to popularizing conservation among the general public, are highly commendable. Mr. Gunasekara is also a senior member and a former president of the Young Zoologists' Association (YZA) of Sri Lanka. Suggested vernacular names are

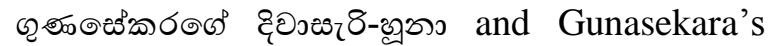
Day-gecko, in Sinhala and English, respectively.

Comparison. Cnemaspis gunasekarai sp. nov. is most similar to C. nilgala, C. hitihamii, and other congeners of the alwisi group. Its diagnostic characters within that group are listed in Table 2. The new species is distinct from its only sympatric Cnemaspis species, $C$. retigalensis Wickramasinghe \& Munindradasa, 2007, by having homogeneous (heterogeneous) dorsal granules, enlarged subcaudals (not enlarged), no precloacal pores (present), ten femoral pores (3-4), gular scales smooth (keeled), 89-95 mid body scale rows (69-77), and 117-126 paravertebral granules (82-86).

The new species is distinguished from $C$. kandambyi Batuwita \& Udugampala, 2017; $C$. 


\section{Plate 03}
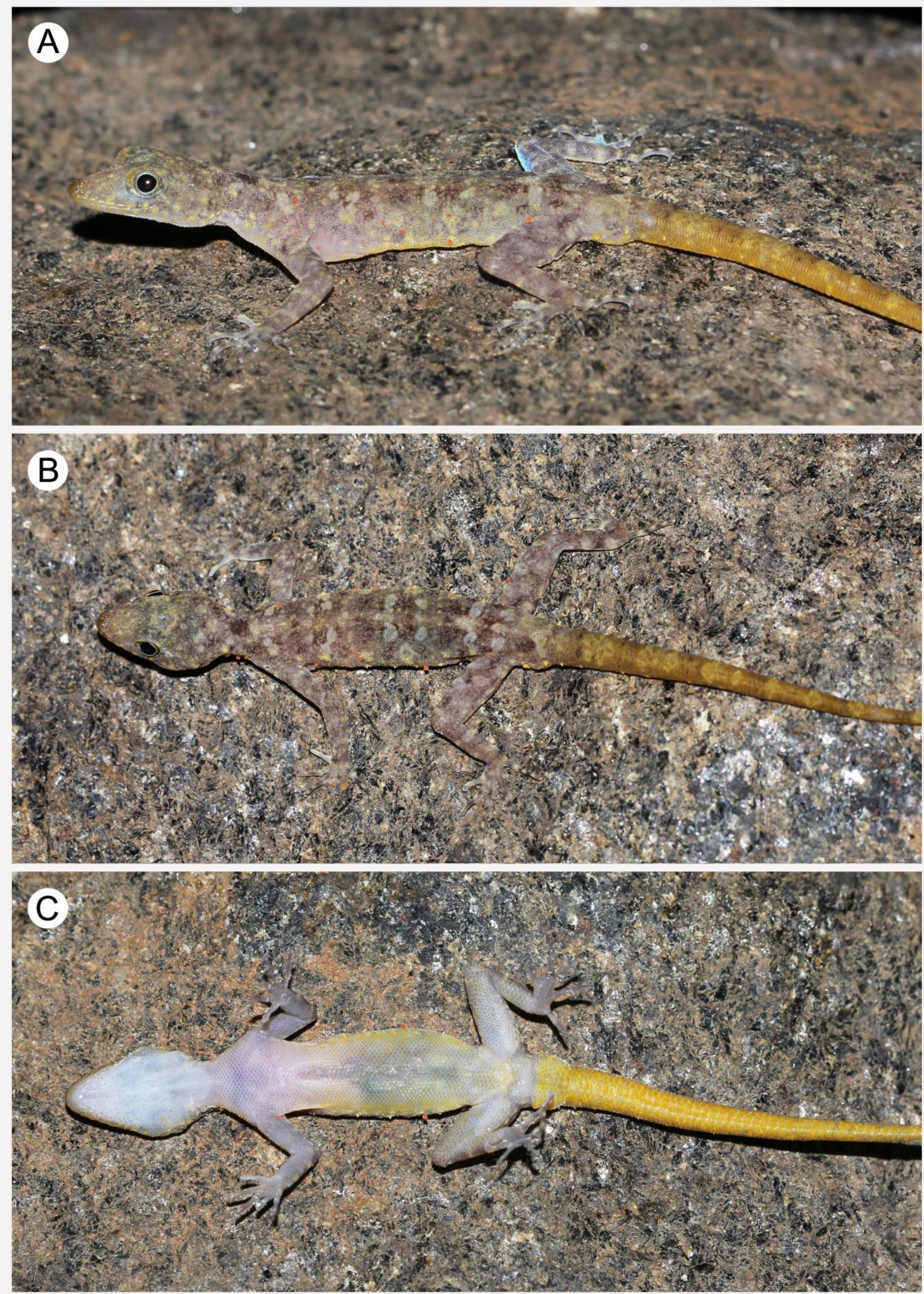

Figure 1. Cnemaspis gunasekarai sp. nov. holotype in life (NMSL 2019.17.01) (A) dorsolateral (B) dorsal, and (C) ventral views. 


\section{Plate 04}

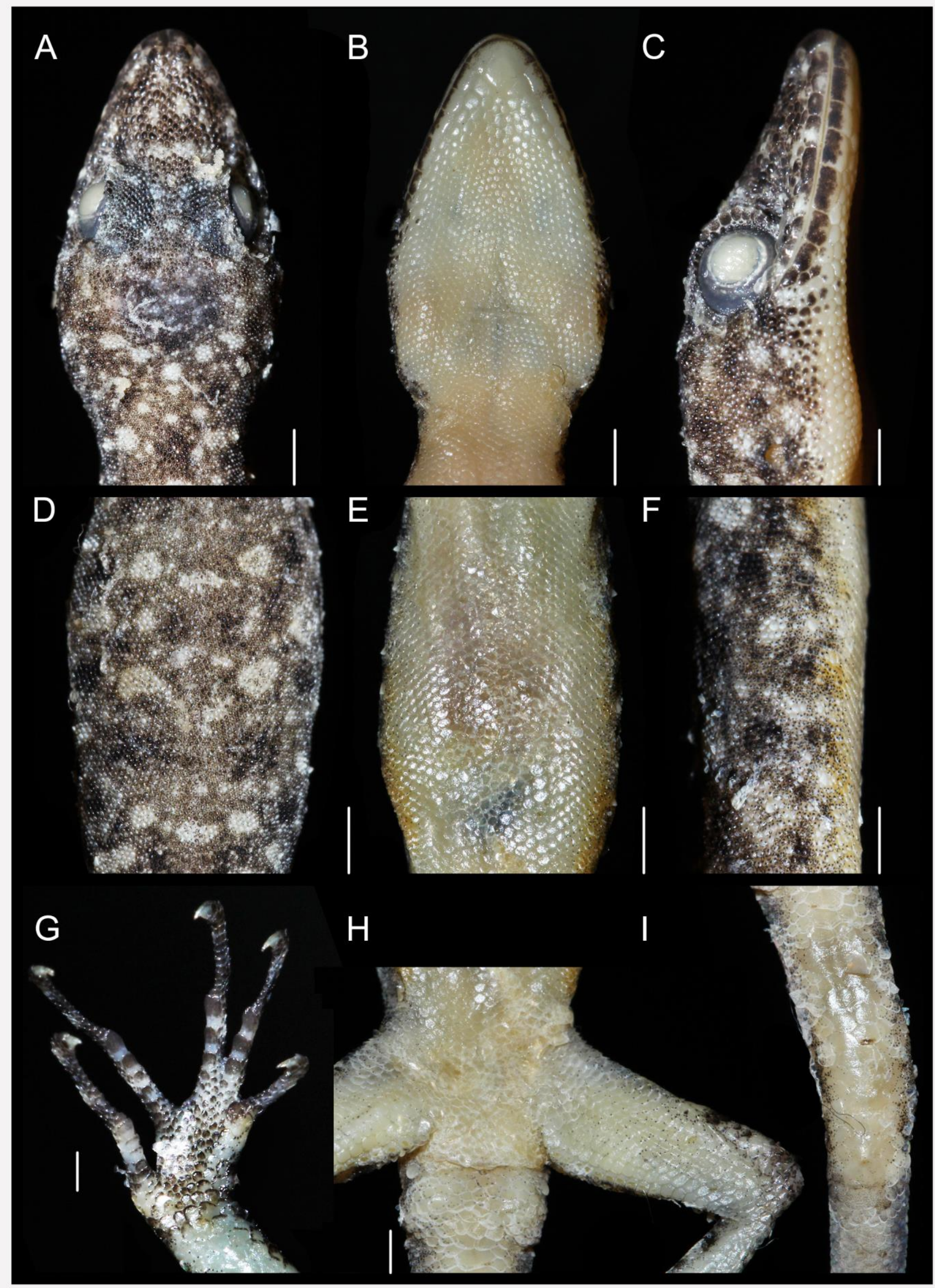

Figure 2. Cnemaspis gunasekarai sp. nov. holotype (NMSL 2019.17.01) head in (A) dorsal view, (B) ventral view, (C) lateral view; midbody in (D) dorsal view, (E) ventral view, (F) lateral view; and ventral view of (G) foot and toes, (H) cloacal area, and (I) tail (Scale: $1 \mathrm{~mm}$ ). 


\section{Plate 05}

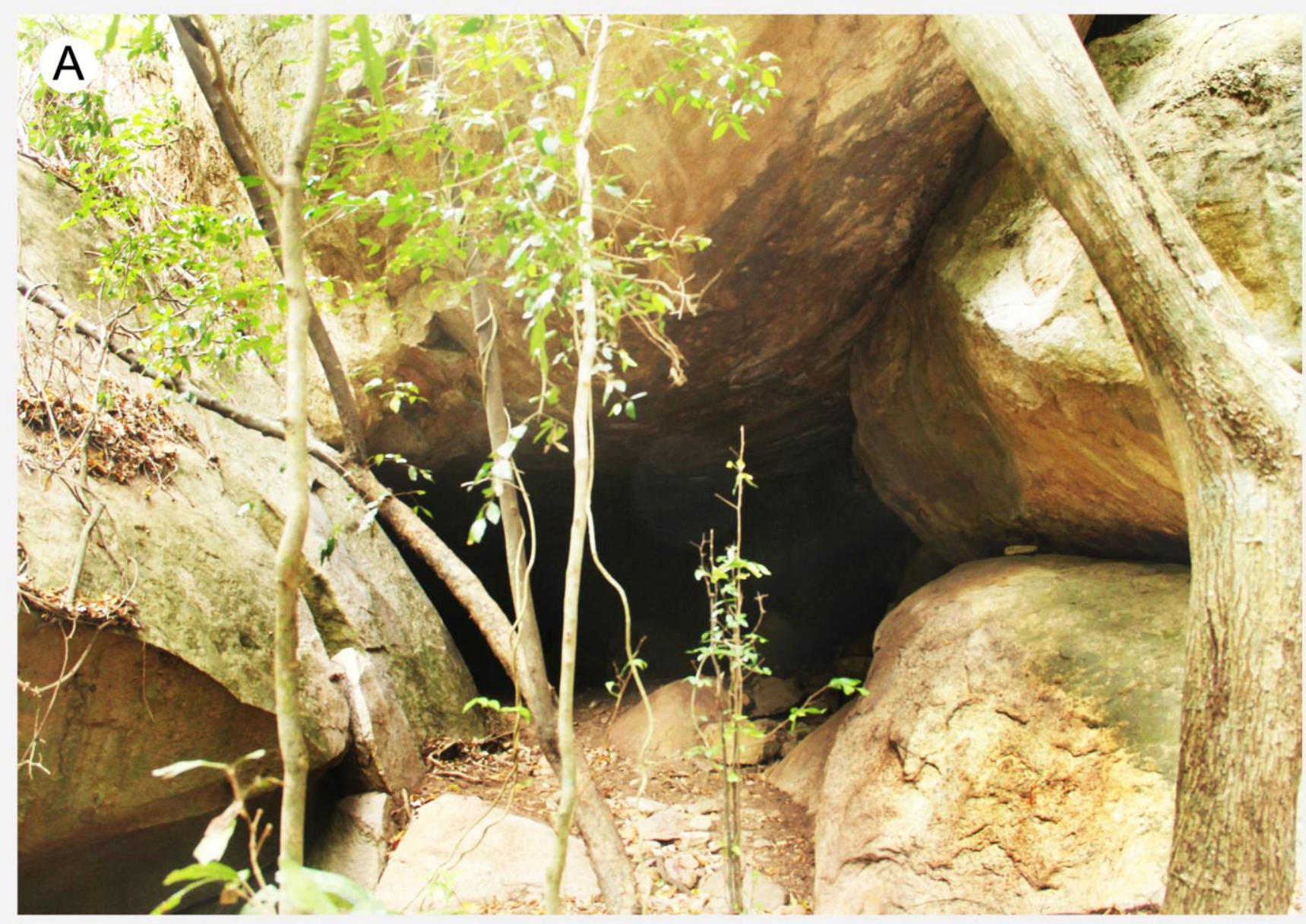

\section{B}

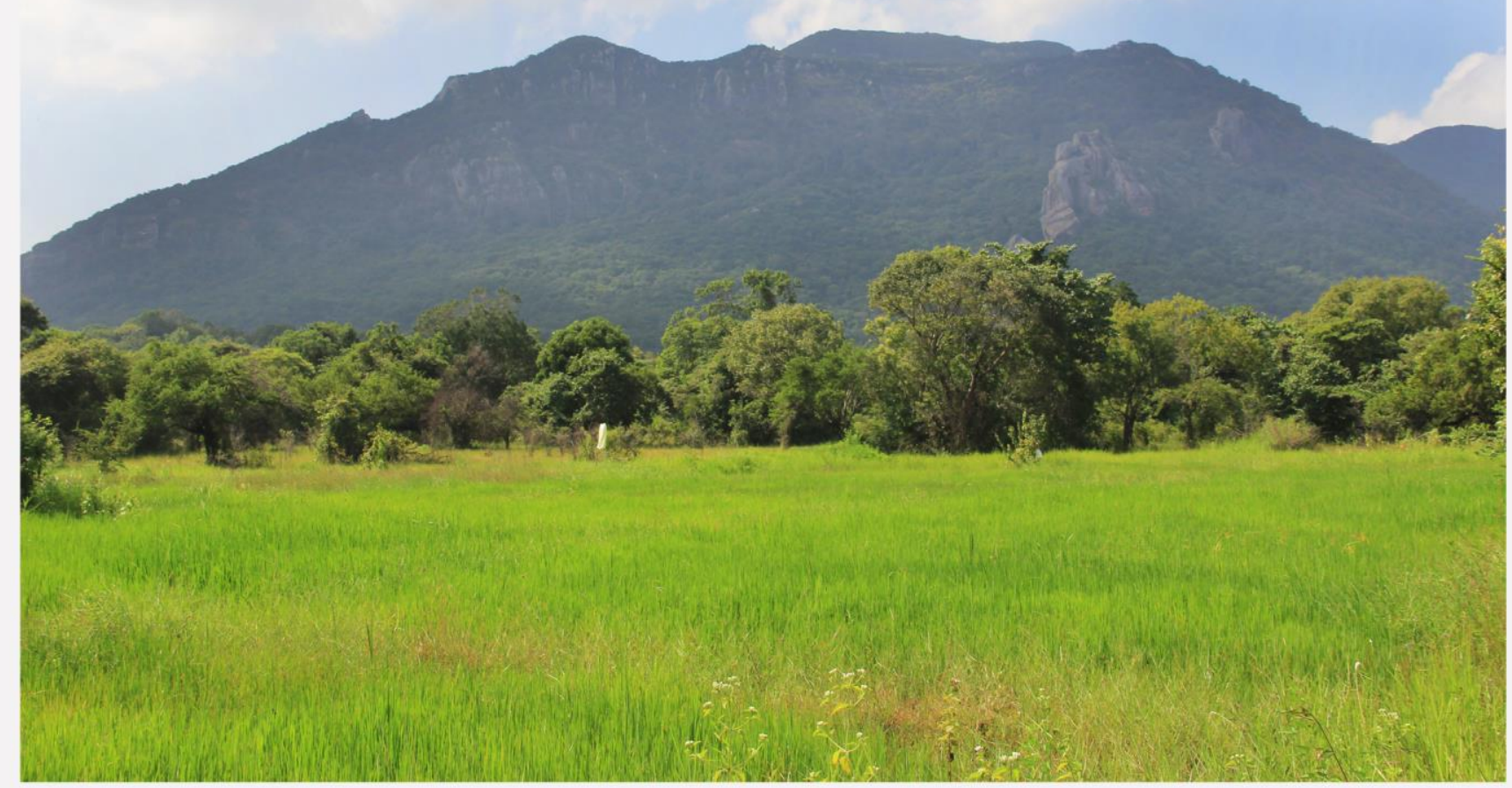

Figure 3. Habitat of Cnemaspis gunasekarai sp. nov. (A) holotype locality, and (B) Ritigala isolated mountain range in Anuradhapura District, North Central Province, Sri Lanka 
molligodai Wickramasinghe \& Munindradasa, 2007; C. podihuna Deraniyagala, 1944, and $C$. manoae Amarasinghe \& Karunarathna, 2020 by having no precloacal pores in males (present), 20-22 ventral scales across belly (15-19), 89-95 mid body scale rows (71-83), ten femoral pores in males (5-9), 119-127 ventrals (128-137 in $C$. kandambyi and $C$. molligodai), 117-126 paravertebral granules (less than 106 in $C$. kandambyi, C. molligodai, and C. podihuna), and 20 or 21 lamellae beneath fourth toe (15-16 in C. manoae).

The new species is distinguished from Cnemaspis scalpensis (Ferguson, 1877); C. gemunu Bauer, de Silva, Greenbaum et al., 2007; C. phillipsi Manamendra-Arachchi, Batuwita \& Pethiyagoda, 2007; C. godagedarai de Silva, Bauer, Botejue et al., 2019; and $C$. anslemi Karunarathna \& Ukuwela, 2019 by having ten femoral pores in males (11-16), 16 interfemoral scales (7-14), 119-127 ventrals (less than 118 in C. anslemi and C. gemunu, and more than 128 in $C$. godagedarai and $C$. phillipsi), 20-22 ventral scales across belly (less than 19 in C. gemunu and C. scalpensis), 89-95 mid body scale rows (less than 88 in $C$. gemunu and $C$. scalpensis, and more than 98 in $C$. godagedarai), 117-126 paravertebral granules (less than 112 in C. gemunu, C. godagedarai, and $C$. scalpensis), and 4 or 5 spine-like tubercles on flank (9-11 in C. scalpensis).

Unlike the new species, all the species listed below have no enlarged median subcaudals: Cnemaspis butewai Karunarathna, Poyakov, de Silva et al., 2019b; C. ingerorum Batuwita, Agarwal \& Bauer, 2019; C. kallima Manamendra-Arachchi, Batuwita \& Pethiyagoda, 2007; C. kandiana (Kelaart, 1852); C. kivulege darai Karunarathna, Poyakov, de Silva et al., 2019b; C. kotagamai Karunarathna, de Silva, Botejue et al., 2019c; C. menikay ManamendraArachchi, Batuwita \& Pethiyagoda, 2007; C. retigalensis; C. pava Manamendra-Arachchi, Batuwita \& Pethiyagoda, 2007; C. pulchra Manamendra-Arachchi, Batuwita \& Pethiyagoda, 2007; C. samanalensis Wickramasinghe \& Munindradasa, 2007; C. silvula ManamendraArachchi, Batuwita \& Pethiyagoda, 2007; $C$. tropidogaster (Boulenger, 1885); C. upendrai Manamendra-Arachchi, Batuwita \& Pethiyagoda, 2007; C. amith Manamendra-Arachchi, Batuwita \& Pethiyagoda, 2007; C. dissanayakai Karunarathna, de Silva, Madawala et al., 2019c; C. gotaimbarai Karunarathna, Poyakov, de Silva et al., 2019b; C. kawminiae Karunarathna, de
Silva, Gabadage et al., 2019c; C. kumarasinghei Wickramasinghe \& Munindradasa, 2007; C. latha Manamendra-Arachchi, Batuwita \& Pethiyagoda, 2007; C. nandimithrai Karunarathna, Poyarkov, de Silva et al., 2019b, and $C$. lokugei Karunarathna, de Silva, Gabadage et al., 2021.

Furthermore, $C$. butewai, $C$. ingerorum, $C$. kallima, C. kandiana, C. kivulegedarai, C. kotagamai, C. menikay, C. pava, C. pulchra, C. retigalensis, $C$. samanalensis, $C$. silvula, $C$. tropidogaster, C. upendrai, and C. lokugei have heterogeneous dorsal granules ( $v s$ homogeneous in C. gunasekarai sp. nov.). Finally, C. pava, $C$. pulchra, $C$. samanalensis, $C$. silvula, $C$. tropidogaster, and $C$. upendrai have keeled ventral scales ( $v s$ smooth in C. gunasekarai sp. nov.).

Distribution and natural history. The new species occurs in Ritigala $\left(8^{\circ} 05^{\prime} 27.63^{\prime \prime}-8^{\circ} 09^{\prime}\right.$ $5.19^{\prime \prime} \mathrm{N}, 80^{\circ} 37^{\prime} 28.62^{\prime \prime}-80^{\circ} 41^{\prime} 22.53 " \mathrm{E}$; alt. 160 $580 \mathrm{~m}$ a.s.l) Anuradhapura District, North Central Province. Ritigala is a wet forest patch on an isolated mountain range in the northcentral dry zone of the island. This range is mostly covered with dry mixed evergreen forest (Gunatileke \& Gunatileke 1990) dominated by tall canopy trees and massive, rocky habitats and caves. The mean annual rainfall varies between 1,500 and $2,000 \mathrm{~mm}$, received mainly during the northeast monsoon (November- February). The mean annual temperature of the area is 29.5$30.8{ }^{\circ} \mathrm{C}$. Based on our observations, the species appears to be very common and widely distributed within its range, which is 2400 ha in size. Our survey of 15 ha revealed $46( \pm 0.3)$ geckos per search-hour. All individuals were found on dry, shaded, cool surfaces of large rock outcrops or sometimes within caves. They were never observed on tree trunks, and never reported in surrounding anthopogenic habitats. The rocky microhabitats were poorly illuminated (light intensity 0-564 Lux), relatively moist (relative humidity $66-78 \%$ and canopy cover 70-90\%) and moderately cool (ambient temperature $30.5-31.9{ }^{\circ} \mathrm{C}$ and substrate temperature $28.4-29.7^{\circ} \mathrm{C}$ ). We observed several gravid females, adhesive eggs, and juveniles; they usually lay 2 or 3 eggs at a time and eggs are slightly elliptical [compared to the members of kandiana clade]. This new species is sympatric with several other gecko species: Cnemaspis retigalensis, Cyrtodactylus yakhuna, Gehyra mutilata, Hemidactylus depressus, $H$. frenatus, $H$. parvimaculatus, and $H$. triedrus. 
Conservation status. The application of the IUCN Red List criteria shows that $C$. gunasekarai sp. nov. is Critically Endangered (CR) because it is restricted to a single location of an area of occupancy (AOO) $2.5 \mathrm{~km}^{2}$ and the extent of occurrence (EOO) is $6.5 \mathrm{~km}^{2}$ in a wet forest patch in the dry zone [Applicable criteria is B1a,b (iii)] documented around ten scattered sites with $\sim 100 \mathrm{~m}$ distance from each other. The species has not been recorded outside the forest. See the maps (Figs. 6, 7) for known distribution.

Cnemaspis gunawardanai sp. nov. [urn:1sid:zoobank.org:act:E29CBF1A-8943-43D1-BB225691E9272532]

(Figs. 4-7, Tables 1-4)

Cnemaspis cf. alwisi - Amarasinghe et al. 2016, Amarasinghe \& Karunarathna 2020

Holotype. Adult male, NMSL 2021.08.01, SVL $37.4 \mathrm{~mm}$, collected from Pilikuttuwa $\left(7^{\circ} 03^{\prime} 28.14^{\prime \prime} \mathrm{N}, 80^{\circ} 02^{\prime} 53.18^{\prime \prime} \mathrm{E}\right.$; alt. $52 \mathrm{~m}$ a.s.1.), Gampaha District, Western Province, Sri Lanka, by Anslem de Silva on 22 November 2005.

Paratype $(n=1)$. Adult female, NMSL 2021.08.02, SVL $40.5 \mathrm{~mm}$; other details are the same as holotype. See Table 1 for morphometric and meristic characters.

Diagnosis. The following combination of characters distinguishes the new species from all other congeners: adult males reaching $37.4 \mathrm{~mm}$ SVL, adult females reaching $40.5 \mathrm{~mm} \mathrm{SVL} ; 8$ or 9 supralabials; dorsal granules homogeneous, 148-155 paravertebral granules; three or four spine-like tubercles on flanks; throat, pectoral, and abdominal scales smooth; 159-162 ventrals; no precloacal pores and six or seven femoral pores (per thigh) in males, 23 interfemoral scales; 96-98 midbody scales, 25-27 ventral scale rows across belly; 22 or 23 subdigital lamellae on fourth toe; subcaudals smooth, hexagonal shaped, median row of subcaudals greatly enlarged; the differences are summarized for geographically close congeners (Table 2) and for all Sri Lankan species in Karunarathna et al. (2019c, and their table 9).

Description of holotype. Characters of holotype followed, when appropriate, by those of paratype (NMSL 2021.08.02) in parenthesis. An adult male, $37.4 \mathrm{~mm} \mathrm{SVL}$ (female $40.5 \mathrm{~mm}$ ); head moderately large, elongate, narrow, distinct from neck, its length $27.8 \%$ of SVL (25.9\%); head width $61.5 \%$ of head length $(59.0 \%)$ and $17.1 \%$ of SVL (15.3\%); snout elongate, its length $70.3 \%$ of head width $(77.4 \%)$ and greater than orbit diameter; orbit diameter $77.8 \%$ of snout length (68.7\%); interorbital region narrow; interorbital distance $20.2 \%$ of head length (18.1\%); eye large, orbit diameter $33.6 \%$ of head length $(31.4 \%)$; pupil rounded; ear-opening deep, oval; diameter of orbits greater than orbit to ear distance, orbit-ear distance $94.3 \%$ of orbit diameter (90.9\%); scales of snout smooth, larger than those of occipital region; scales of interorbital, superciliary, and gular regions granular; rostral scale partially divided by medial groove, postero-ventrally in contact with first supralabial, contacted posteriorly by two nasals and two subcircular supranasals; single internasal scales between supranasals; nostrils oval, dorsally orientated; three postnasals, lowest in broad contact with first and second supralabials; nasals in broad contact with first supralabial.

Mental subtriangular, elongate and shortened posteriorly to level of first supralabial, wider than long, postero-laterally in contact with two enlarged postmentals; postmentals medially separated by a single postmental scale; postmentals bordered posteriorly by three smooth scales on both sides, including the medial scale; scales on throat smooth, juxtaposed; bluntly pointed scales on side of neck, similar in size to those at mid-dorsum; three scale rows separating orbit from supralabials at level of pupil; nine supralabials (8); eight infralabials, decreasing in size towards angle of jaw.

Body slender, elongate; axilla-groin distance $46.5 \%$ of SVL (43.4\%); mid-dorsal granules bluntly pointed, homogeneous, keeled; four spine-like tubercles on flank; dorsal scales at midbody smaller than ventrals at same level; paravertebral granules 155 (148); pectoral and abdominal scales subequal in size, smooth, bluntly pointed, overlapped; ventral scales in 27 (25) rows across belly, ventro-lateral scales on trunk bluntly pointed and smooth; no distinct ventrolateral fold; scales around midbody 98 (96); ventrals 159 (162); no precloacal pores and six femoral pores on left thigh and seven on right (absent as the paratype is a female).

Arms moderately short; length of brachium $14.7 \%$ of SVL (14.6\%); length of antebrachium $15.5 \%$ of SVL (16.5\%); legs relatively long; shank length $19.5 \%$ of SVL (18.0\%); thigh shorter than shank, its length $18.4 \%$ of SVL 


\section{Plate 06}

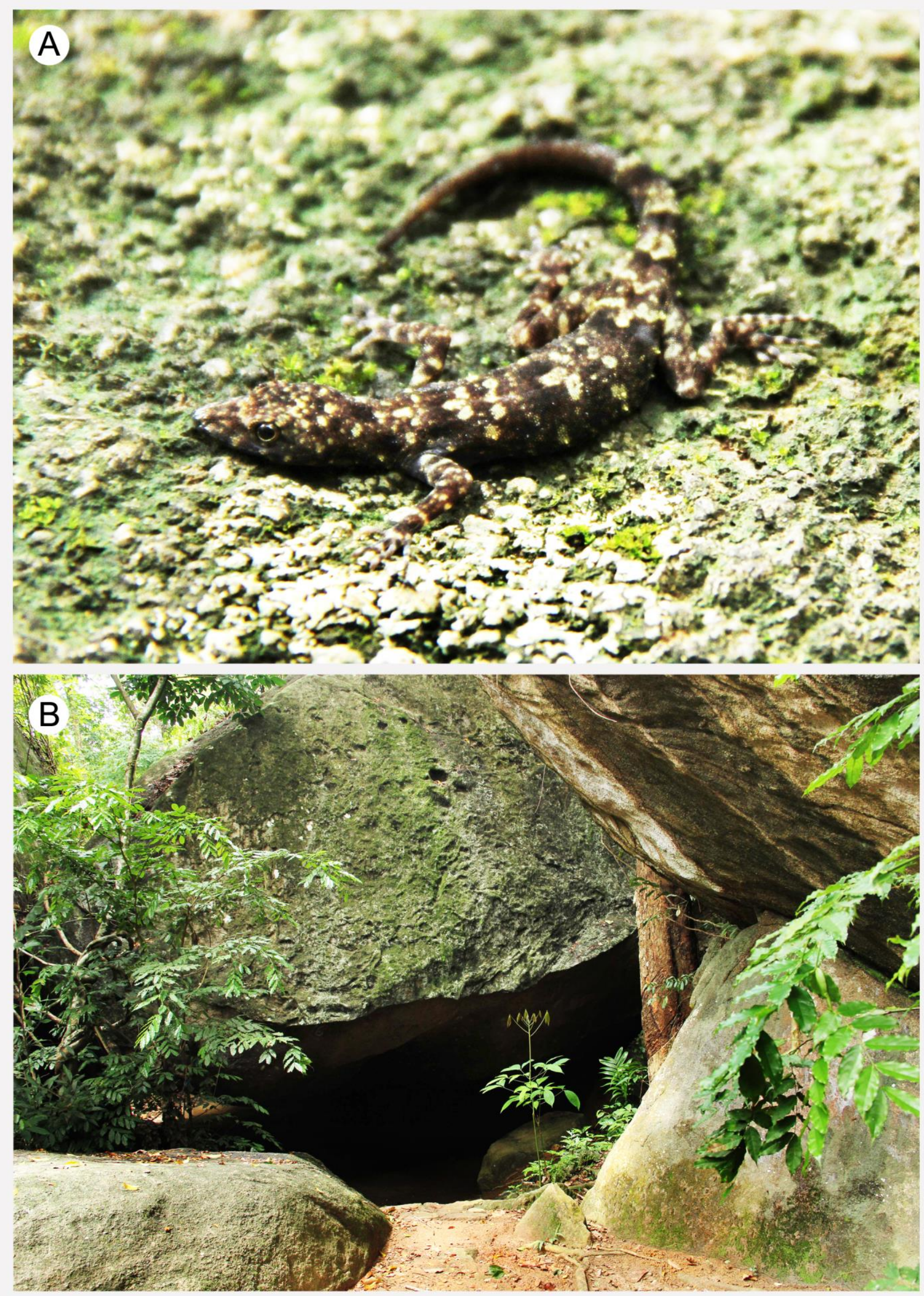

Figure 4. Cnemaspis gunawardanai sp. nov. (A) dorsolateral view of the holotype in life (NMSL 2021.08.01) (B) rocky and cave habitat at the type locality, Pilikuttuwa, near the capital of Sri Lanka. 


\section{Plate 07}

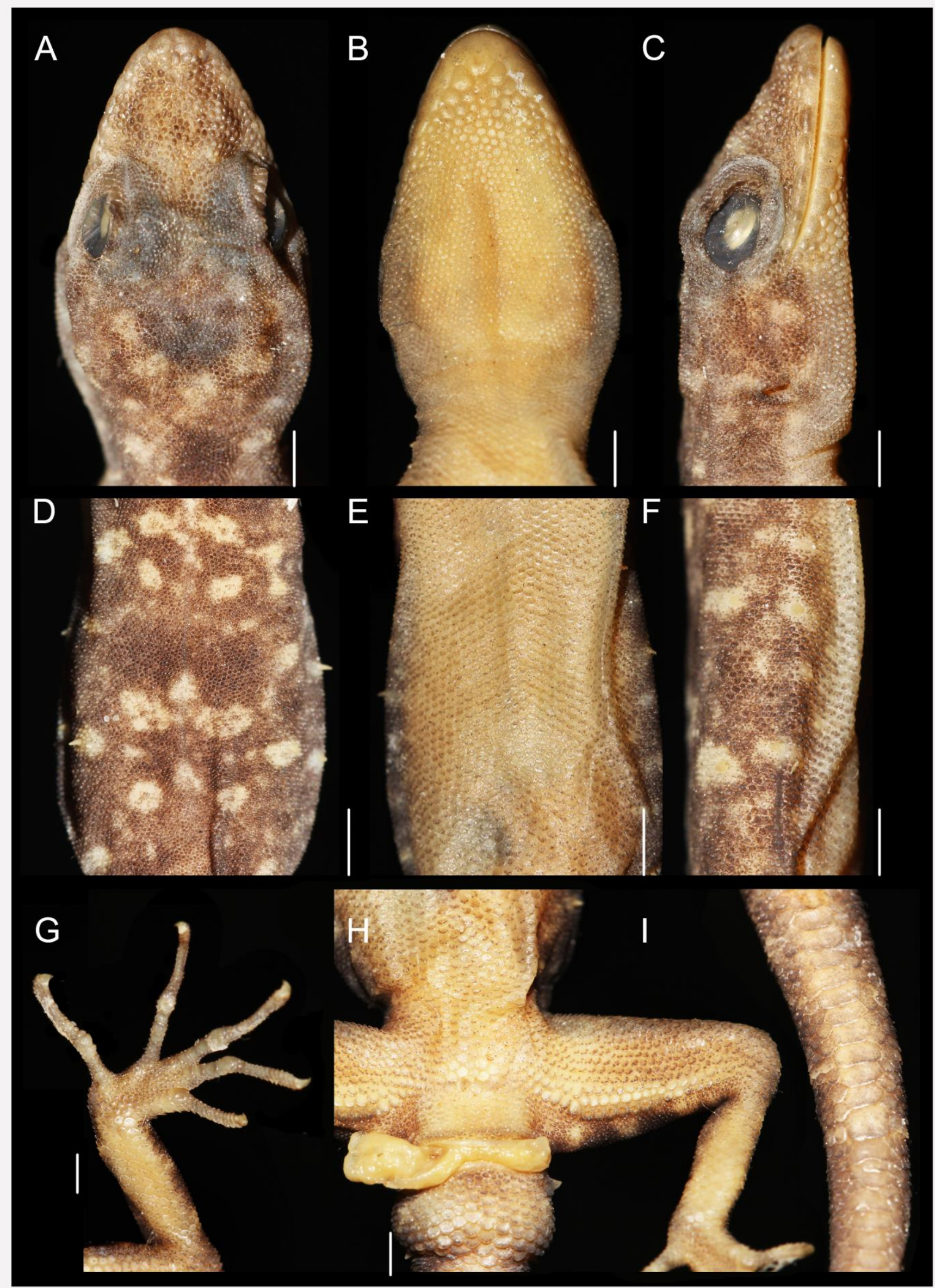

Figure 5. Cnemaspis gunawardanai sp. nov. holotype (NMSL 2021.08.01) head in (A) dorsal view, (B) ventral view, (C) lateral view; midbody in (D) dorsal view, (E) ventral view, (F) lateral view; and ventral view of (G) foot and toes, (H) cloacal area, and (I) tail (Scale: $1 \mathrm{~mm}$ ). 
(18.0\%); dorsal scales on both arms and legs bluntly pointed and not enlarged; ventral scales on brachium granular and smooth, scales on antebrachium enlarged; scales on ventral surface of thigh bluntly pointed and smooth; digits elongate, slender, all bearing slightly recurved claws; subdigital lamellae entire, 22 on toe IV (23); inter-digital webbing absent; relative lengths of fingers and toes IV $>$ III $>$ V $>$ II $>$ I.

Tail complete, original, distal half regenerated; tail base swollen; two pairs of postcloacal spurs; dorsal scales on tail bluntly pointed, imbricate, and smooth; dorsal tail scales homogeneous and enlarged in size; dorsal tail with 4-5 enlarged obtuse scales forming whorls on anterior tail; subcaudal scales at tail base small, bluntly pointed, enlarged and smooth; median subcaudal row enlarged, wide and hexagonal in both original and regenerated tail.

Variation. See Table 1.

Coloration. In life, the holotype had a dorsal pattern of cream and yellowish vertebral markings on a uniform dark brown background color; snout light brown; the neck had a black spot, and a vertebral cream stripe shading posteriorly; several pale and dark blotches scattered on the dorsum, middorsally visible like flower petals; arms and legs uniform dark brown with pale and dark blotches; dark brown tail had six pale yellow markings on the original tail, the regenerated tail uniform brown; ventral side of the whole body white.

After 15 years in preservative, the cream pigment has faded to yellowish brown and background color to brown. The ventral body, head, and tail faded to light brownish yellow.

Etymology. The specific epithet is a noun in the genitive singular case, honoring a leading environmental activist, conservationist, and a lawyer, Dr. Jagath Gunawardana for his major efforts and contributions to biodiversity conservation in Sri Lanka, as well as his support, motivation, and encouragements for the first three authors to accomplish their research and career goals. His valuable contributions to popularizing environmental law among the general public are highly commendable. Currently he is an advisor to many government institutions such as Central Environmental Authority (CEA), Department of Wildlife Conservation and Department of Forestry etc. Dr. Gunawardana is also a senior member and a former instructer of the Young Zoologists' Association (YZA) of Sri Lanka. Suggested

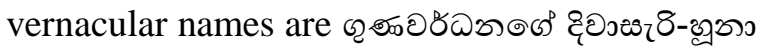

and Gunawardana's Day-gecko, in Sinhala and English, respectively.

Comparison. Cnemaspis gunawardanai sp. nov. is most similar to $C$. rajakarunai, $C$. hitihamii, and other congeners of the alwisi group, and its diagnostic characters within that group are listed in Table 2. The new species distinctly differs from its two sympatric Cnemaspis species, C. manoae by having no precloacal pores in males (present), 6 or 7 femoral pores in males (9), 59-162 ventrals (117-121), 25-27 ventral scale rows across belly (15-17), 96-98 scale rows at mid body (79-83), 148-155 paravertebral granules (119-126), 2123 lamellae beneath fourth toe (15-16); and from $C$. tropidogaster by having homogeneous dorsal granules (heterogeneous), smooth ventral side (keeled), enlarged subcaudals (not enlarged), no precloacal pores (present).

The new species is distinguished from $C$. kandambyi, C. molligodai, and C. podihuna by having no precloacal pores in males (present), 25-27 ventral scales across belly (15-19), 96-98 mid body scale rows (71-83), 159-162 ventrals (less than 135), and 148-155 paravertebral granules (less than 126); from Cnemaspis scalpensis, $C$. gemunu, $C$. phillipsi, $C$. godagedarai, and $C$. anslemi by having 6 or 7 femoral pores in males (11-16), 23 interfemoral scales (7-14), 159-162 ventrals (less than 143), 25-27 ventral scales across belly (less than 23 in C. anslemi, C. geтипи C. godagedarai, and $C$. scalpensis), 96-98 mid body scale rows (less than 91 in C. anslemi, C. gemunu C. phillipsi, and $C$. scalpensis, and more than 98 in $C$. godagedarai), 148-155 paravertebral granules (less than 112), and 3 or 4 spine-like tubercles on flank (9-11 in C. scalpensis).

Unlike the new species, none of the species listed below have enlarged median subcaudals: Cnemaspis butewai, C. ingerorum, C. kallima, C. kandiana, C. kivulegedarai, C. kotagamai, $C$. menikay, C. retigalensis; C. pava, C. pulchra, $C$. samanalensis, C. silvula, C. tropidogaster, $C$. upendrai, $C$. amith, $C$. dissanayakai, $C$. gotaimbarai, C. kawminiae, C. kumarasinghei, $C$. latha, C. nandimithrai, and C. lokugei. Furthermore, C. butewai, $C$. ingerorum, $C$. kallima, C. kandiana, C. kivulegedarai, C. kotagamai, C. menikay, C. pava, C. pulchra, C. retigalensis, $C$. samanalensis, $C$. silvula, $C$. tropidogaster, C. upendrai, and C. lokugei have heterogeneous dorsal granules ( $v s$ homogeneous in C. gunawardanai sp. nov.). Finally, C. pava, C. pulchra, C. samanalensis, C. silvula, $C$. 
tropidogaster, and $C$. upendrai have keeled ventral scales (vs smooth in $C$. gunawardanai sp. nov.).

Distribution and natural history. The new species occurs in two localities: Pilikuttuwa $\left(7^{\circ} 03^{\prime} 28^{\prime \prime} \mathrm{N}, 80^{\circ} 02^{\prime} 53^{\prime \prime} \mathrm{E}\right)$ and Maligatenna ( $\left.7^{\circ} 04^{\prime} 04^{\prime \prime} \mathrm{N}, 80^{\circ} 03^{\prime} 50^{\prime \prime} \mathrm{E}\right)$, Gampaha District, Western Province. These forested areas are of lowland tropical rainforest vegetation (Gunatilleke \& Gunatilleke 1990) but the massive, rocky outcrops and caves create a local dry-mixed habitat. The core study area was approximately $2.5 \mathrm{~km} \times 1.5 \mathrm{~km}(\sim 500 \mathrm{ha})$, at an elevation range of approximately $40-160 \mathrm{~m}$ a.s.l. Based on our observations in 2020, all individuals were found on dry, shaded, cool surfaces of rock outcrops inside caves (Fig. 4), rarely outside. We did not observe any eggs or juveniles but did observe several gravid females. Usually 2 or 3 geckos (individuals per searchhour) were recorded at these two localities. They were never observed on tree trunks and were never reported in surrounding anthopogenic habitats.

Table 1. Morphometric (in $\mathrm{mm}$ ) and meristric character comparisons of holotype and paratypes of Cnemaspis gunasekarai sp. nov. and C. gunawardanai sp. nov

\begin{tabular}{|c|c|c|c|c|c|}
\hline \multirow{5}{*}{ Character } & \multicolumn{3}{|c|}{$\begin{array}{l}\text { Cnemaspis gunasekarai sp. nov. } \\
(n=3)\end{array}$} & \multicolumn{2}{|c|}{$\begin{array}{l}\text { Cnemaspis gunawardanai sp. nov. } \\
\qquad(n=2)\end{array}$} \\
\hline & \multirow{4}{*}{$\begin{array}{c}\text { male } \\
\text { holotype } \\
\text { (NMSL } \\
2019.17 .01)\end{array}$} & \multicolumn{2}{|c|}{ females } & \multirow{4}{*}{$\begin{array}{c}\text { male } \\
\text { holotype } \\
\text { (NMSL } \\
2021.08 .01)\end{array}$} & \multirow{4}{*}{$\begin{array}{c}\text { female } \\
\text { paratype } \\
\text { (NMSL } \\
2021.08 .02)\end{array}$} \\
\hline & & paratype & paratype & & \\
\hline & & (NMSL & (NMSL & & \\
\hline & & 2019.17.02) & 2019.17.03) & & \\
\hline snout-vent length & 34.6 & 31.1 & 28.6 & 37.4 & 40.5 \\
\hline axilla-groin length & 14.6 & 13.2 & 12.9 & 17.4 & 17.6 \\
\hline head length & 9.9 & 9.7 & 9.6 & 10.4 & 10.5 \\
\hline head width & 4.9 & 4.6 & 4.6 & 6.4 & 6.2 \\
\hline orbit diameter & 3.4 & 3.2 & 3.2 & 3.5 & 3.3 \\
\hline orbit-ear distance & 2.9 & 2.7 & 2.7 & 3.3 & 3.0 \\
\hline snout length & 3.7 & 3.5 & 3.5 & 4.5 & 4.8 \\
\hline orbit-nostril length & 2.8 & 2.8 & 2.7 & 3.4 & 3.6 \\
\hline interorbital width & 3.8 & 3.7 & 3.7 & 2.1 & 1.9 \\
\hline ear diameter & 0.9 & 0.7 & 0.7 & 1.0 & 1.0 \\
\hline internarial length & 1.6 & 1.4 & 1.4 & 1.3 & 1.7 \\
\hline brachium length & 5.5 & 5.1 & 5.1 & 5.5 & 5.9 \\
\hline antebrachium length & 5.0 & 4.8 & 4.8 & 5.8 & 6.7 \\
\hline palm length & 3.9 & 3.4 & 3.5 & 5.0 & 5.6 \\
\hline finger $\mathrm{I}-\mathrm{V}$ lengths & $\begin{array}{c}2.2,2.7,2.9 \\
3.2,2.5\end{array}$ & $\begin{array}{c}1.9,2.5,2.7 \\
3.1,2.1\end{array}$ & $\begin{array}{c}1.9,2.5,2.7 \\
2.9,2.2\end{array}$ & $\begin{array}{c}2.2,3.3,3.4 \\
\quad 3.5,3.1\end{array}$ & $\begin{array}{c}2.2,3.4,3.7 \\
\quad 3.9,3.3\end{array}$ \\
\hline thigh length & 6.2 & 5.8 & 5.7 & 6.9 & 8.3 \\
\hline shank length & 6.1 & 5.1 & 5.1 & 7.3 & 7.3 \\
\hline foot length & 5.4 & 4.4 & 4.4 & 4.8 & 5.1 \\
\hline toe I-V lengths & $\begin{array}{c}2.1,3.1,3.6 \\
\quad 4.1,3.8\end{array}$ & $\begin{array}{c}1.9,2.8,3.2 \\
3.9,3.7\end{array}$ & $\begin{array}{l}1.8,2.7,3.1 \\
3.7,3.4\end{array}$ & $\begin{array}{l}2.5,4.2,4.0 \\
\quad 4.7,3.7\end{array}$ & $\begin{array}{l}2.5,3.7,4.2 \\
\quad 4.8,3.6\end{array}$ \\
\hline tail length & 39.3 & 34.9 & 32.8 & 42.7 & 38.0 \\
\hline Supralabials (L/R) & 10,11 & 9 & 10 & 9 & 8 \\
\hline Infralabials (L/R) & 9 & 8,9 & 9 & 8,9 & 8 \\
\hline ventrals & 127 & 119 & 122 & 159 & 162 \\
\hline ventral scale rows & 22 & 20 & 21 & 27 & 25 \\
\hline midbody scale rows & 95 & 89 & 91 & 98 & 96 \\
\hline lamellae finger $\mathrm{I}-\mathrm{V}$ & $\begin{array}{l}10,15,16 \\
17,15\end{array}$ & $\begin{array}{c}11,14,17 \\
16,14\end{array}$ & $\begin{array}{l}10,14,17 \\
17,14\end{array}$ & $\begin{array}{c}15,16,18,21, \\
16\end{array}$ & $\begin{array}{c}14,15,18,20, \\
17\end{array}$ \\
\hline lamellae toe $\mathrm{I}-\mathrm{V}$ & $\begin{array}{c}10,14,16 \\
21,18\end{array}$ & $\begin{array}{c}12,13,16 \\
20,17\end{array}$ & $\begin{array}{c}11,14,16 \\
21,17\end{array}$ & $\begin{array}{c}15,17,21,22 \\
18\end{array}$ & $\begin{array}{c}15,16,19,23, \\
17\end{array}$ \\
\hline precloacal pores & absent & absent & absent & absent & absent \\
\hline femoral pores & 10 & absent & absent & 6,7 & absent \\
\hline interfemoral scales & 16 & absent & absent & 23 & absent \\
\hline
\end{tabular}




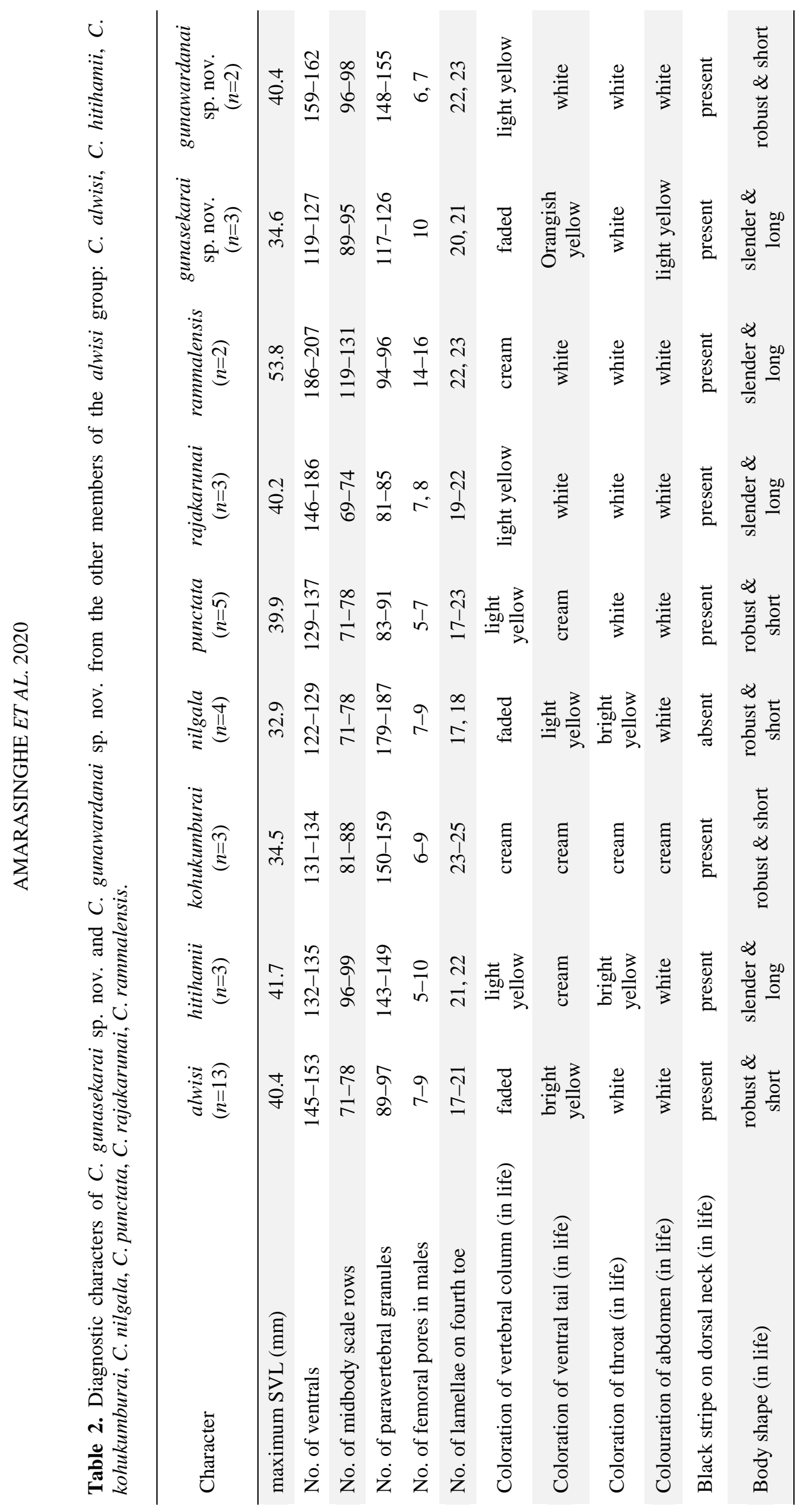


Conservation status. The application of the IUCN Red List criteria shows that $C$. gunawardanai sp. nov. is Critically Endangered (CR) because it is restricted to an area of occupancy (AOO) $<0.6 \mathrm{~km}^{2}$ and the extent of occurrence (EOO) is $<2.5 \mathrm{~km}^{2}$ in the wet zone [criteria B1a,b(iii)] assuming that the two sites documented here are the extent of the species' range. However, confirmation that the species does not occur in adjacent areas should be sought before a final determination on conservation status is made. Surrounding habitats of the type locality are currently being converted to pineapple plantations (see Amarasinghe \& Karunarathna 2020), rubber is invading the natural forests, and illegal logging in the forest was observed (Fig. 5).

\section{Discussion}

With the description of these two new species, the richness of the Cnemaspis fauna in Sri Lanka reaches 40 species, all with $100 \%$ endemism to the island. Based on previous studies, Cnemaspis is known for its tendency to occupy various habitats, with some species frequenting caves, rock crevices, tree bark, claywalls and others foraging in leaf litter. Many species occur in the mid elevations (400-600 $\mathrm{m}$ a.s.l.), but some are restricted to highlands or montane areas (1200-1800 $\mathrm{m}$ a.s.l.), and some are isolated to wet forest patches in the lowland dryzone (Amarasinghe \& Karunarathna 2020). Amarasinghe \& Karunarathna (2020) further discussed the current geographic distribution of the podihuna clade and provided a table linking each member of that clade to each biogeographic region. Here we update that table with the two new species (Table 3). The members of the alwisi group are widely distributed surrounding the central highlands, but so far not recorded from higher altitudes (Fig. 7).

Interestingly, all the species in the alwisi group (podihuna clade) are rupicolous, mosly occupy rock crevices, rock surfaces and caves (Table 4). In contrast, members of the other two groups of the podihuna clade, the scalpensis and podihuna groups are arboreal species, except Cnemaspis gemunu and Cnemaspis godagedarai. Among the three species groups (alwisi, scalpensis, and podihuna) within podihuna clade, the rupicolous alwisi group shows higher species richness (nine species) compared to the other two groups (five and four species respectively).

Table 3. Current distribution patterns of the Cnemaspis species of the podihuna clade in each biogeographic region (revised and modified after Amarasinghe \& Karunarathna 2020); “_” not recorded yet.

\begin{tabular}{|c|c|c|c|}
\hline \multirow{2}{*}{ Biogeographic region (alt. range a.s.l.) } & \multicolumn{3}{|c|}{ podihuna clade } \\
\hline & scalpensis group & podihuna group & alwisi group \\
\hline \multicolumn{4}{|l|}{ (1). Wet Zone } \\
\hline Lowland $(0-400 \mathrm{~m})$ & - & $\begin{array}{l}\text { C. molligodai } \\
\text { C. manoae }\end{array}$ & $\begin{array}{c}\text { C. rajakarunai } \\
\text { C. gunawardanai sp. nov. }\end{array}$ \\
\hline Rakwana hills (above $400 \mathrm{~m}$ ) & C. godagedarai & - & - \\
\hline Central highland submontane (400-900 m) & $\begin{array}{l}\text { C. scalpensis } \\
\text { C. anslemi }\end{array}$ & - & C. kohukumburai \\
\hline Central highland montane (above $900 \mathrm{~m}$ ) & С. gетипи & - & - \\
\hline \multicolumn{4}{|l|}{ (2). Intermediate Zone } \\
\hline Lowland $(0-400 \mathrm{~m})$ & - & - & $\begin{array}{c}\text { C. alwisi } \\
\text { C. rammalensis }\end{array}$ \\
\hline Uva hills (above $300 \mathrm{~m}$ ) & - & - & C. nilgala \\
\hline Central highland submontane (400-900 m) & - & - & C. hitihamii \\
\hline Knuckles submontane (400-900 m) & C. phillipsi & C. kandambyi & C. punctata \\
\hline Knuckles montane (above 900 m) & C. phillipsi & - & C. punctata \\
\hline \multicolumn{4}{|l|}{ (3). Dry Zone } \\
\hline Lowland $(0-400 \mathrm{~m})$ & - & C. podihuna & $\begin{array}{c}\text { C. nilgala } \\
\text { C. gunasekarai sp. nov. }\end{array}$ \\
\hline
\end{tabular}




\section{Plate 08}

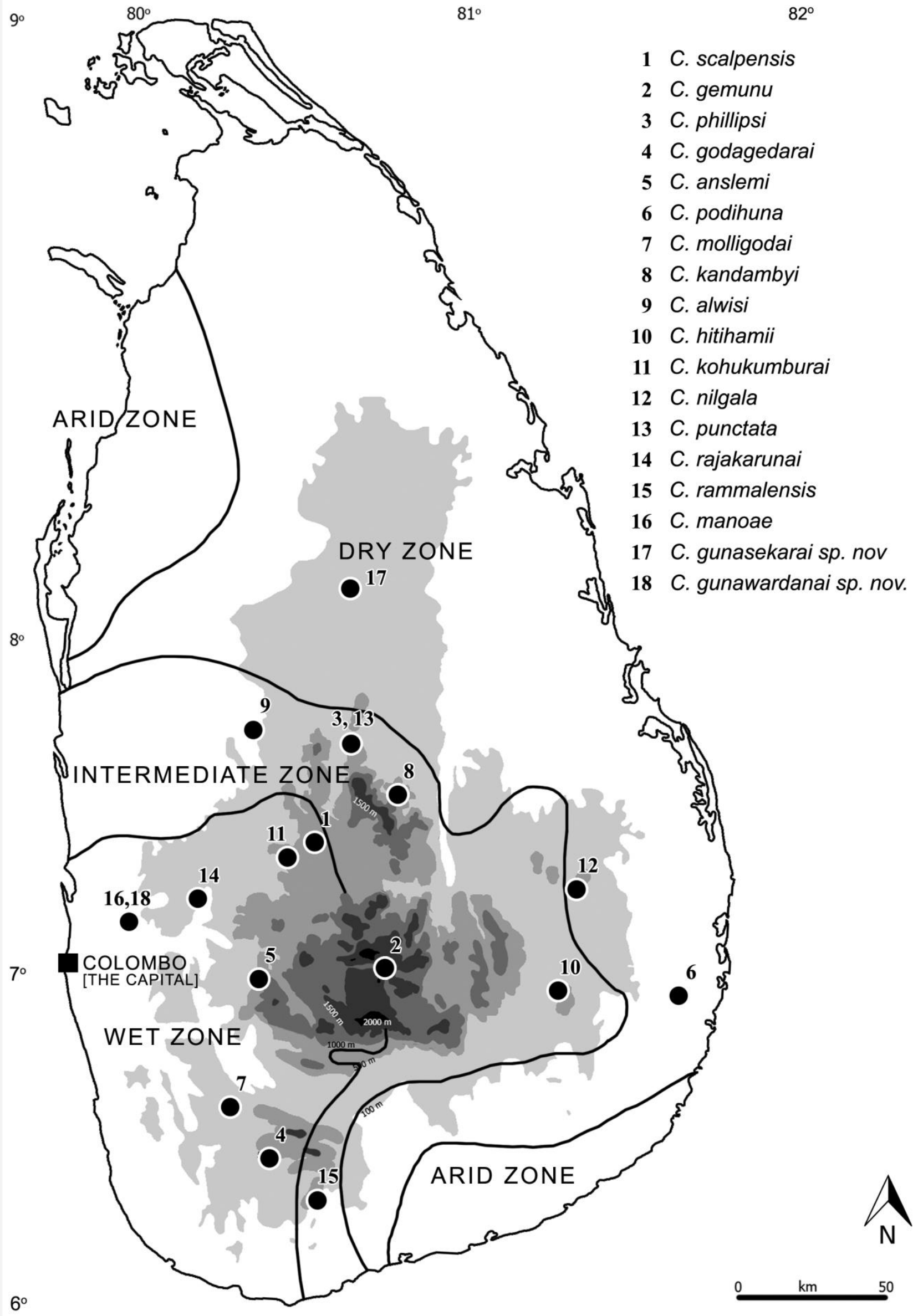

Figure 6. Current distribution map of the Cnemaspis species of the podihuna clade in Sri Lanka; the holotype locality of each species is marked with a circle (modified after Amarasinghe \& Karunarathna 2020). 
Table 4. Habitat preference of the species of the genus Cnemaspis in Sri Lanka; a.g.l., above ground level

\begin{tabular}{|c|c|c|c|c|c|c|}
\hline \multirow[b]{2}{*}{$\frac{\frac{\pi}{\pi}}{\circlearrowright}$} & \multirow{2}{*}{ 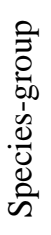 } & \multirow[b]{2}{*}{ Species } & \multicolumn{4}{|c|}{ Habitat } \\
\hline & & & $\begin{array}{l}\text { Rocky } \\
\text { crevices, caves } \\
\text { rock surface }(2< \\
\text { m a.g.l. })\end{array}$ & $\begin{array}{l}\text { Aboreal } \\
\text { on tree } \\
\text { trunks }(2< \\
\text { m a.g.l. })\end{array}$ & $\begin{array}{c}\text { Forest floor } \\
\text { mostly on tree basel } \\
(>2 \mathrm{~m}), \text { and under } \\
\text { rock boulders }\end{array}$ & $\begin{array}{c}\text { Anthropogenic } \\
\text { wattle and daub } \\
\text { houses near forest } \\
\text { edge }\end{array}$ \\
\hline \multirow{21}{*}{ 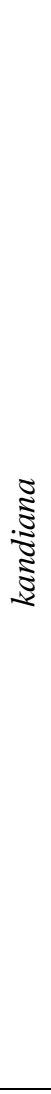 } & \multirow{9}{*}{ 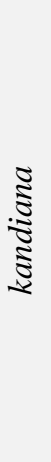 } & C. butewai & $*$ & & & \\
\hline & & C. ingerorum & $*$ & & & \\
\hline & & C. kallima & $*$ & $*$ & $*$ & $*$ \\
\hline & & C. kandiana & $*$ & $*$ & $*$ & $*$ \\
\hline & & C. kivulegedarai & $*$ & & & $*$ \\
\hline & & C. kotagamai & $*$ & & & $*$ \\
\hline & & C. lokugei & $*$ & & & $*$ \\
\hline & & C. menikay & $*$ & & & $*$ \\
\hline & & C. retigalensis & $*$ & & $*$ & $*$ \\
\hline & \multirow{6}{*}{ 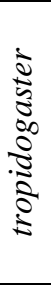 } & C. pava & $*$ & & & $*$ \\
\hline & & C. pulchra & $*$ & & & $*$ \\
\hline & & C. samanalensis & $*$ & $*$ & $*$ & $*$ \\
\hline & & C. silvula & $*$ & $*$ & $*$ & $*$ \\
\hline & & C. tropidogaster & $*$ & & & $*$ \\
\hline & & C. upendrai & $*$ & & & $*$ \\
\hline & \multirow{6}{*}{ 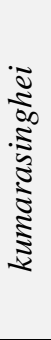 } & C. dissanayakai & $*$ & & & $*$ \\
\hline & & C. gotaimbarai & $*$ & & & $*$ \\
\hline & & C. kawminiae & $*$ & & & $*$ \\
\hline & & C. kumarasinghei & $*$ & $*$ & & $*$ \\
\hline & & C. latha & $*$ & & & $*$ \\
\hline & & $\begin{array}{l}\text { C. nandimithrai } \\
\text { C. amith }\end{array}$ & $*$ & & & $*$ \\
\hline \multirow{18}{*}{ 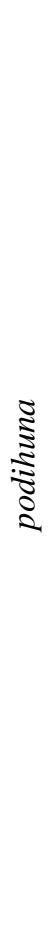 } & \multirow{4}{*}{ 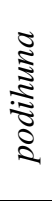 } & C. kandambyi & & $*$ & & \\
\hline & & C. molligodai & & $*$ & & \\
\hline & & C. podihuna & & $*$ & & $*$ \\
\hline & & C. manoae & & $*$ & & $*$ \\
\hline & \multirow{5}{*}{ 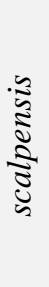 } & C. anslemi & & $*$ & & $*$ \\
\hline & & C. gетипи & $*$ & & & $*$ \\
\hline & & C. godagedarai & $*$ & & & $*$ \\
\hline & & C. phillipsi & & $*$ & & $*$ \\
\hline & & C. scalpensis & & $*$ & & $*$ \\
\hline & \multirow{9}{*}{$\frac{\tilde{s}}{3}$} & C. alwisi & $*$ & & & $*$ \\
\hline & & C. hitihamii & $*$ & & & $*$ \\
\hline & & C. kohukumburai & $*$ & & & \\
\hline & & C. nilgala & $*$ & $*$ & & $*$ \\
\hline & & C. punctata & $*$ & & & $*$ \\
\hline & & C. rajakarunai & $*$ & & & $*$ \\
\hline & & C. rammalensis & $*$ & & & \\
\hline & & C. gunasekarai sp. nov. & $*$ & & & $*$ \\
\hline & & C. gunawardanai sp. nov. & $*$ & & & $*$ \\
\hline
\end{tabular}


It seems the rupicolous species show higher speciation compared to the arboreal species of this genus, probably due to the isolation in and adaptation to clustered rocky habitats scattered in wet, intermediate and dry bioclimatic zones. Supporting this hypothesis, we have identified as many as 15 more unnamed distinct Cnemaspis taxa from Sri Lanka, likely to be species (work in progress by Karunarathna et al.). Interestingly, all of these are rupicolous and belong to the alwisi and kandiana groups. Among the currently known species of the genus Cnemaspis in Sri Lanka, only seven (17.5\%) are fully arboreal, and the rest (33 species, $82.5 \%$ ) are mainly rupicolous. Six of them $(15 \%)$ have been observed on tree trunks, probably occupying trees as a secondary habitat during daytime (Table 4). Agarwal et al. (2020) suggested that granite boulders act as climate refugia for the Cnemaspis in India, and it seems this is also true for the species in Sri Lanka.

We have noticed that in some localities, the species that belong to either different groups or clades live sympatrically but have never observed species from the same species-group in sympatry. For example, Pilikuttuwa in Gampaha district is identified as a Cnemaspis hotspot where three species of Cnemaspis from three different species groups occur syntopically. Cnemaspis tropidogaster (tropidogaster group, kandiana clade) and C. gunawardanai sp. nov. (alwisi group, podihuna clade) share the same rocky habitats. Cnemaspis tropidogaster occupies the rock crevices and $C$. manoae (podihuna group, podihuna clade) occupies the trees, and during daytime they thrive openly in shady and cool places on the rock surface and tree trunks respectively, while $C$. gunawardanai sp. nov. is mostly found hiding inside caves. We found both $C$. tropidogaster and $C$. gunawardanai sp. nov. together on the same rock boulder, and it would be interesting to study inter-specific relationship of these two sympatric species. Also, we found $C$. gunawardanai sp. nov. in low numbers compared to C. tropidogaster and C. manoae.

Similarly, in Ritigala, Anuradhapura District, both rock-dwelling $C$. retigalensis (kandiana group, kandiana clade) and $C$. gunasekarai sp. nov. (alwisi group, podihuna clade) occupy syntopically the same habitat. Mostly $C$. gunasekarai sp. nov. is found in rock crevises and on the surface, while C. retigalensis is inside caves, and only rarely found on the forest floor or the base of trees (within $2 \mathrm{~m}$ from the ground level).

\section{Key to day geckos of the genus Cnemaspis in Sri Lanka}

(modified after Amarasinghe \& Karunarathna 2020)

1. (a) Subcaudals not enlarged ............................. 2 (kandiana clade)

(b) Subcuadals enlarged 23 (podihuna clade)

2. (a) Dorsal granules homogeneous 3 (kumarasinghei group)

(b) Dorsal granules heterogeneous 8

3. (a) Gular scales smooth ................................... 4

(b) Gular scales keeled ........................ C. amith

4. (a) Paravertebral granules 61-79 ..................... 5

(b) Paravertebral granules $86-99 \ldots \ldots \ldots \ldots \ldots \ldots \ldots . . . .6$

(c) Paravertebral granules 105-121 ….............. 7

5. (a) Ventrals $109-115$, midbody scales $69-73 \ldots \ldots .$. (b) Ventrals $120-134$, midbody scales $87-94 \ldots . . . .$. C. kumarasinghei

6. (a) Lamellae on fourth toe 15 or 16 , midbody scales 76-78 .................................. C. kawminiae (b) Lamellae on fourth toe 19-20, midbody scales 87-89 ......................... C. nandimithrai

7. (a) Midbody scales $72-79$, lamellae on fourth toe 19 or 20, ventrals $129-138$........ C. gotaimbarai (b) Midbody scales 94-98, lamellae on fourth toe 21 or 22 , ventrals $118-120$......... C. dissanayakai

8. (a) Pectoral and abdominal scales smooth ......... 9 (kandiana group)

(b) Pectoral and abdominal scales keeled ........ 17 (tropidogaster group)

9. (a) Gular scales smooth ............................... 10

(b) Gular scales keeled .................................. 14

10. (a) Ventrals 88-114 ..................................... 11

(b) Ventrals 131-159 ................................... 12

11. (a) Paravertebral granules 93-101, lamellae on fourth toe 17 or 18 , flank spines 7 or 8

C. ingerorum

(b) Paravertebral granules 131-133, lamellae on fourth toe 14-16, flank spines 4 or 5

C. kivulegedarai

12. (a) Flank spines 5 or 7 , paravertebral granules 114-132, midbody scales 79-103 .................. 13

(b) Flank spines 12-15, paravertebral granules 99-107, midbody scales 67-74 ......... C. kallima 
13. (a) Ventrals 131-137, scale rows across belly 2122 , midbody scale rows $79-84$, one precloacal pore (in males)

C. kotagamai (b) Ventrals 143-159, scale rows across belly 1517, midbody scale rows 95-103, 3 precloacal pores (in males) C. lokugei

14. (a) Midbody scales 68-79, paravertebral granules 82-99 ........................................ 15 (b) Midbody scales 92-98, paravertebral granules 134-138

C. butewai

15. (a) Flank spines $4-7$ 16

(b) Flank spines 13-15

C. menikay

16. (a) One precloacal pore (in males)

(b) 2-4 precloacal pores (in males)

C. retigalensis

C. kandiana

17. (a) Paravertebral granules $83-113$ 18

(b) Paravertebral granules 64-72

C. samanalensis

18. (a) Flank spines 5-7 19

(b) Flank spines 9-15 20

19. (a) Midbody scales 67-73 C. pulchra (b) Midbody scales 92-98 C. tropidogaster

20. (a) Paravertebral granules 83-113 21 (b) Paravertebral granules 64-72

C. samanalensis

21. (a) Ventrals 132-145 22

(b) Ventrals 112-128 C. upendrai

22. (a) Paravertebral granules 83-98 C.pava (b) Paravertebral granules 102-113 ...... C. silvula

23. (a) Precloacal pores present (in males) 24 (podihuna group)

(b) Precloacal pores absent (in males) 27 (scalpensis + alwisi groups)

24. (a) Ventrals 111-121, paravertebral granules 102-126, lamellae on fourth toe 15-19 ......... 25 (b) Ventrals 127-137, paravertebral granules 7692 , lamellae on fourth toe 19-23 ................. 26

25. (a) Paravertebral granules $102-106,3$ or 4 precloacal pores (in males), 3-6 femoral pores (in males), lamellae on fourth toe 18 or 19

C. podihuna

(b) Paravertebral granules 119-126, 5 precloacal pores (in males), 9 femoral pores (in males), lamellae on fourth toe 15 or 16 C. manoae

26. (a) Paravertebral granules $76-83,8$ or 9 femoral pores (in males) C. molligodai (b) Paravertebral granules $85-92,5$ or 6 precloacal pores (in males) .......... C. kandambyi

27. (a) Midbody scales 69-102 _..................... 28

(b) Midbody scales 119-131 ....... C. rammalensis (alwisi group)

28. (a) Femoral pores 11-16 (in males) ............... 29 (scalpensis group)

(b) Femoral pores 5-10 (in males) ................ 33

(alwisi group)

29. (a) Paravertebral granules 79-93, lamellae on fourth toe 17-19 ...................................... 30

(b) Paravertebral granules 101-122, lamellae on fourth toe 20 or 21

31

30. (a) Ventrals $112-118$, flank spines 7 or $8,11-14$ femoral pores (in males) ................. . geтипи (b) Ventrals 128-143, flank spines 4-6, 15 or 16 femoral pores (in males) ................... C. phillipsi

31. (a) Paravertebral granules 102-112, ventrals 120-137 ................................................. 32 (b) Paravertebral granules 118-122, ventrals 111-117 ........................................ C. anslemi

32. (a) Midbody scales 81-89, flank spines 9-11, ventrals $120-131$....................... C. scalpensis (b) Midbody scales $98-102$, flank spines 5 or 6, ventrals $133-137$ C. godagedarai

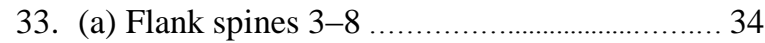
(b) Flank spines 11-13 C. punctata

34. (a) Paravertebral granules 81-97 35

(b) Paravertebral granules 117-187 .............. 36

35. (a) Paravertebral granules $81-85$

(b) Paravertebral granules 89-97

C. rajakarunai C. alwisi

36. (a) Ventrals 119-135 .................................. 37

(b) Ventrals 159-162 ... C. gunwardanai sp. nov.

37. (a) Flank spines $3-5$ 38

(b) Flank spines 7-8 C. kohukumburai

38. (a) Ventrals 119-129, interfemoral scales 14-16 ....................................................... 39 (b) Ventrals 132-135, interfemoral scales 24-26 C. hitihamii

39. (a) Ventrals 122-129, scales across belly 17-19, midbody scale rows 71-78, paravertebral granules 179-155, lamellae on fourth toe 17-18 C. nilgala (b) Ventrals 159-162, scales across belly 25-27, midbody scale rows 96-98, paravertebral granules $148-155$, lamellae on fourth toe 22 or 23

C. gunasekarai sp. nov. 


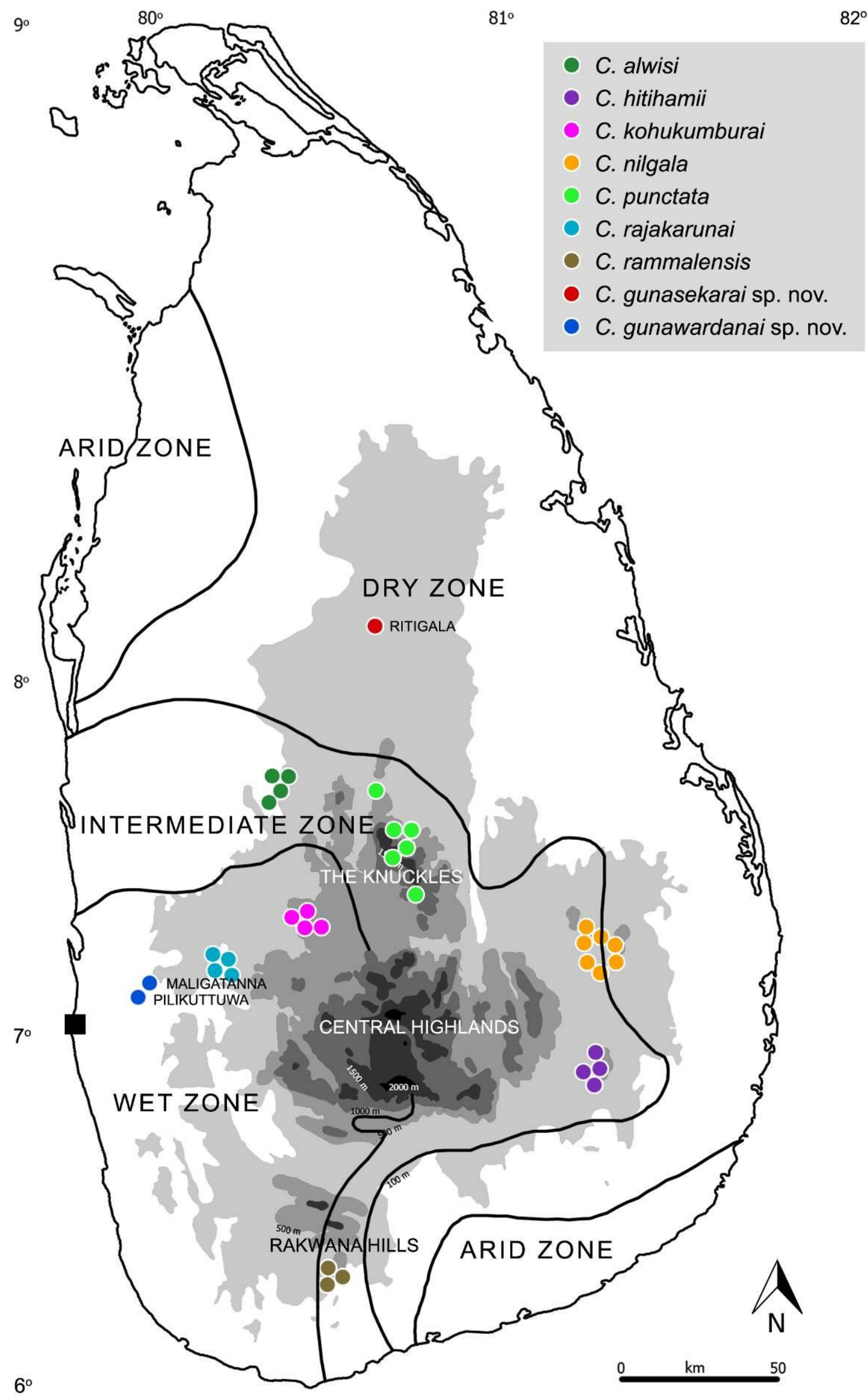

Figure 7. Current distribution map of the Cnemaspis species of the alwisi group in Sri Lanka 


\section{Acknowledgments}

We thank the Department of Wildlife Conservation (Permit no. WL/3/2/1/14/12) for granting research permit to AdS; N. Wickramasinghe (former director), S. Kasthuriarachchi (director), L. Somaratne, C. Munasinghe, T. Gamage, R. Dasanayake, R. Wickramanayake, and P. Gunasiri at NMSL for facilitating the in-house study of specimens; Kanishka Ukuwela, Sanoj Wijayasekara, Thaveesha de Alwis, Buddhika Mawella, Sanjaya Bandara, Nirmala Perera, Hiranya Sudasinghe, Dinesh Gabadage, Madhava Botejue, Gayan Edirisinghe, Sulakshana Wickramarachchi, Hasantha Wijethunga and Niranjan Karunarathna for field assistance; S.R. Chandramouli (Pondicherry University), Ivan Ineich (Muséum National d'Histoire Naturelle, Paris), and L. Lee Grismer (La Sierra University, California) for valuable comments; J. Supriatna and the staff of the Research Center for Climate Change, University of Indonesia for their support.

\section{Literature cited}

Agarwal, I., S. Biswas, A.M. Bauer, E. Greenbaum et al. (2017). Cryptic species, taxonomic inflation, or a bit of both? New species phenomenon in Sri Lanka as suggested by a phylogeny of dwarf geckos (Reptilia, Squamata, Gekkonidae, Cnemaspis). Systematics \& Biodiversity, 15 (5): 1-13.

Agarwal, I., T. Thackeray, S. Pal, A. Khandekar (2020). Granite boulders act as deep-time climate refugia: a Miocene divergent clade of rupicolous Cnemaspis Strauch, 1887 (Squamata: Gekkonidae) from the Mysore Plateau, India, with descriptions of three new species. Journal of Zoological Systematics and Evolutionary Research, 58 (4): 1234-1261.

Amarasinghe, A.A.T., M.B. Harvey, A. Riyanto, and E.N. Smith (2015). A new species of Cnemaspis (Reptilia: Gekkonidae) from Sumatra, Indonesia. Herpetologica, 71 (2): 160-167.

Amarasinghe, A.A.T. and P.D. Campbell (2016). On the rediscovery of the Cnemaspis podihuna Deraniyagala, 1944 (Reptilia: Gekkonidae) holotype at the Natural History Museum, London. Zootaxa, 4137 (2): 296-300.

Amarasinghe, A.A.T., P.D. Campbell, M.B. Madawala, W.M.S. Botejue et al. (2016). The redescovery of live population of Cnemaspis tropidogaster (Boulenger, 1885) (Sauria: Gekkonidae) from Sri Lanka after 120 years. Zootaxa, 4200 (3), 395-405.

Amarasinghe, A.A.T. and S. Karunarathna (2020). A new diminutive day gecko species of the genus Cnemaspis Strauch, 1887 (Reptilia:
Gekkonidae) from Pilikuttuwa, near the capital of Sri Lanka. Taprobanica, 9 (1): 71-82.

Batuwita, S. and S. Udugampala (2017). Description of a new species of Cnemaspis (Squamata: Gekkonidae) from Knuckles Range of Sri Lanka. Zootaxa, 4254 (1): 82-90.

Batuwita, S., I. Agarwal, and A.M. Bauer (2019). Description of a new diminutive, rupicolous species of day-gecko (Squamata: Gekkonidae: Cnemaspis) from southern Sri Lanka. Zootaxa, 4565 (2): 223-234.

Bauer, A.M., A. de Silva, E. Greenbaum, and T. Jackman (2007). A new species of day gecko from high elevation in Sri Lanka, with a preliminary phylogeny of Sri Lankan Cnemaspis (Reptilia: Squamata: Gekkonidae). Mitteilungen aus dem Museum für Naturkunde, Berlin, Zoologische Reihe, 83 (1): 22-32.

Boulenger, G.A. (1885). Catalogue of the Lizards in the British Museum (Natural History). British Museum (Natural History), London: $436 \mathrm{pp}$.

Deraniyagala, P.E.P. (1944). A new Cnemaspis gecko from Ceylon. Journal of Royal Asiatic Society Sri Lanka, 97 (2): 226-227.

de Silva, A., A.M. Bauer, M. Botejue, and S. Karunarathna (2019). A new species of endemic day gecko (Reptilia: Gekkonidae: Cnemaspis) from a wet zone forest in second peneplain of Southern Sri Lanka. Amphibian \& Reptile Conservation, 13 (1): 198-208.

Ferguson, W.M. (1877). Reptile Fauna of Ceylon. Letter on a collection sent to the Colombo Museum. William Henry Herbert, Government Printer, Colombo: 42 pp.

Gamble, T., E. Greenbaum, T.R. Jackman, A.P. Russell, and A.M. Bauer (2012). Repeated origin and loss of adhesive toepads in geckos. Plos One, 7: e39429.

Grismer, L.L., P.L. Wood Jr, S. Anuar, A. Riyanto et al. (2014). Systematics and natural history of Southeast Asian Rock Geckos (genus Cnemaspis Strauch 1887) with descriptions of eight new species from Malaysia, Thailand, and Indonesia. Zootaxa, 3880 (1): 1-147.

Gunatileke, I.A.U.N. and C.V.S. Gunatileke (1990). Distribution of floristic richness and its conservation in Sri Lanka. Conservation Biology, 4 (1): 21-31.

IUCN Standards and Petitions Committee (2019). Guidelines for using the IUCN Red List categories and criteria version 14. Geneva, Switzerland. Prepared by the Standards and Petitions Committee: 113 pp.

Karunarathna, S. and K. Ukuwela (2019). A new species of dwarf day gecko (Reptilia: 
Gekkonidae: Cnemaspis) from lowerelevations of Samanala Nature Reserve in Central Massif, Sri Lanka. Amphibian \& Reptile Conservation, 13 (2): 14-27.

Karunarathna, S., A. Bauer, A. de Silva, T. Surasinghe et al. (2019a). Description of a new species of the genus Cnemaspis Strauch, 1887 (Reptilia: Squamata: Gekkonidae) from the Nilgala Savannah forest, Uva Province of Sri Lanka. Zootaxa, 4545 (3): 389-407.

Karunarathna, S., N.A. Poyarkov, A. de Silva, M. Madawala et al. (2019b). Integrative taxonomy reveals six new species of day geckos of the genus Cnemaspis Strauch, 1887 (Reptilia: Squamata: Gekkonidae) from geographically-isolated hill forests in Sri Lanka. Vertebrate Zoology, 69 (3): 247-298.

Karunarathna, S., A. de Silva, M. Botejue, D. Gabadage et al. (2019c). Three new species of day geckos (Reptilia: Gekkonidae: Cnemaspis Strauch, 1887) from isolated granite cave habitats in Sri Lanka. Amphibian \& Reptile Conservation, 13 (2): 323-354.

Karunarathna, S. A. de Silva, D. Gabadage, M. Botejue et al. (2021). A new species of day gecko (Reptilia, Gekkonidae, Cnemaspis Strauch, 1887) from Sri Lanka with an updated ND2 gene phylogeny of Sri Lankan and Indian species. Zoosystematics \& Evolution, 97 (1): 191-209.

Kelaart, E.F. (1852). Prodromus Faunae Zeylanicae, being contributions to the zoology of Ceylon. volume 1. published by the author, Colombo: $197 \mathrm{pp}$.
Manamendra-Arachchi, K., S. Batuwita, and R. Pethiyagoda (2007). A taxonomic revision of the Sri Lankan day geckos (Reptilia: Gekkonidae: Cnemaspis), with description of new species from Sri Lanka and southern India. Zeylanica, 7 (1): 9-122.

Strauch, A. (1887). Bermerkungen über die Geckonidensammlung im zoologischen Museum der Kaiserlichen Akademie der Wissenschaften zu St. Petersburg. Mémoires de l'Académie Impériale des Sciences de St. Pétersbourg, 35 (7): 1-72.

Uetz, P., S. Cherikh, G. Shea, I. Ineich et al. (2019). A global catalog of primary reptile type specimens. Zootaxa, 4695 (5): 438-450.

Vidanapathirana, D.R., M.D.G. Rajeev, N. Wickramasinghe, S.S. Fernando, and L.J.M. Wickramasinghe (2014). Cnemaspis rammalensis sp. nov., Sri Lanka's largest daygecko (Sauria: Gekkonidae: Cnemaspis) from Rammalakanda Man and Biosphere Reserve in southern Sri Lanka. Zootaxa, 3755 (3): 273286.

Wickramasinghe, L.J.M. and D.A.I. Munindradasa (2007). Review of the genus Cnemaspis Strauch, 1887 (Sauria: Gekkonidae) in Sri Lanka with the description of five new species. Zootaxa, 1490 (1): 1-63.

Wickramasinghe, L.J.M., D.R. Vidanapathirana, and R.M.G.P. Rathnayake (2016). Cnemaspis rajakarunai sp. nov., a rock dwelling daygecko (Sauria: Gekkonidae: Cnemaspis) from Salgala, an unprotected lowland rainforest in Sri Lanka. Zootaxa, 4168 (1): 92-108.

Appendix I. Other specimens examined

Cnemaspis alwisi (13 ex.): Sri Lanka: NMSL 2004.09.01 (holotype), 2004.09.02-03 (paratypes), WHT 5918, 6518-9, 7336-8, 7343-6. C. anslemi (3 ex.): Sri Lanka: NMSL 2019.14.01 (holotype), 2019.14.02-03 (paratypes). C. gemunu (9 ex.): Sri Lanka: AMB 7495 (holotype), 7507 (paratype), WHT 7221, 7347-8, NMSL 2006.11.01-04. C. godagedarai (3 ex.): Sri Lanka: NMSL 2019.09.01 (holotype), 2019.16.01-02 (paratypes). C. hitihamii (3 ex.): Sri Lanka: NMSL 2019.06.01 (holotype), 2019.06.02-03 (paratypes). C. kandambyi (2 ex.): Sri Lanka: WHT 9466 (holotype), 9467 (paratype). C. kohukumburai (3 ex.): Sri Lanka: NMSL 2019.05.01 (holotype), 2019.05.02-03 (paratypes). C. manoae (3 ex.): Sri Lanka: NMSL 2019.10.01 (holotype), 2019.10.02-03 (paratypes). C. molligodai (7 ex.): Sri Lanka: NMSL 2006.14.01 (holotype), 2006.14.02-05 (paratypes), NMSL uncat. (2 specimens). C. nilgala (4 ex.): Sri Lanka: NMSL 2018.07.01 (holotype), 2018.06.01-03 (paratypes). C. phillipsi (4 ex.): Sri Lanka: WHT 7248 (holotype), 7236-8 (paratypes). C. podihuna (4 ex.): Sri Lanka: NHMUK 1946.8.1.20 (holotype), NMSL 2006.10.02-04. C. punctata (5 ex.): Sri Lanka: WHT 7256 (holotype), 7223 (paratype), 7226 (paratype), 7243-4 (paratypes). $\boldsymbol{C}$. rajakarunai (3 ex.): Sri Lanka: NMSL 2016.07.01 (holotype), DWC 2016.05.01-02 (paratypes). C. rammalensis (2 ex.): Sri Lanka: NMSL 2013.25.01 (holotype), DWC 2013.05.001. C. scalpensis (11 ex.): Sri Lanka: NMSL 2004.01.01 (neotype), 2004.02.01, 2004.03.01, 2004.04.01, WHT 7265, 7268-9, 7274-6, 7320. 